Article

\title{
Neodymium Recovery by Chitosan/Iron(III) Hydroxide [ChiFer(III)] Sorbent Material: Batch and Column Systems
}

\author{
Hary Demey ${ }^{1,2, *(\mathbb{D})}$, Byron Lapo ${ }^{1,3}{ }^{(\mathbb{D})}$, Montserrat Ruiz ${ }^{4}$, Agustin Fortuny ${ }^{4}$, Muriel Marchand ${ }^{2}$ \\ and Ana M. Sastre ${ }^{1}$ (D) \\ 1 Department of Chemical Engineering, Universitat Politècnica de Catalunya, ETSEIB, Diagonal 647, \\ 08028 Barcelona, Spain; Byron.lapo@upc.edu (B.L.); Ana.maria.sastre@upc.edu (A.M.S.) \\ 2 Commissariat à l'Energie Atomique et aux Energies Alternatives, CEA/DRT/LITEN/DTBH/LTB, \\ 17 rue des Martrys, 38054 Grenoble, France; muriel.marchand@cea.fr \\ 3 School of Chemical Engineering, Universidad Técnica de Machala, UACQS, 070151 Machala, Ecuador \\ 4 Department of Chemical Engineering, Universitat Politècnica de Catalunya, EPSEVG, Av. Víctor Balaguer, \\ s/n, 08800 Vilanova i la Geltrú, Spain; Montserrat.ruiz@upc.edu (M.R.); agustin.fortuny@upc.edu (A.F.) \\ * Correspondence: hary.demey@upc.edu; Tel.: +34-938-937-778
}

Received: 15 January 2018; Accepted: 16 February 2018; Published: 19 February 2018

\begin{abstract}
A low cost composite material was synthesized for neodymium recovery from dilute aqueous solutions. The in-situ production of the composite containing chitosan and iron(III) hydroxide (ChiFer(III)) was improved and the results were compared with raw chitosan particles. The sorbent was characterized using Fourier transform infrared spectroscopy (FTIR) and scanning electron microscopy-energy dispersive X-ray analyses (SEM-EDX). The equilibrium studies were performed using firstly a batch system, and secondly a continuous system. The sorption isotherms were fitted with the Langmuir, Freundlich, and Sips models; experimental data was better described with the Langmuir equation and the maximum sorption capacity was $13.8 \mathrm{mg} \cdot \mathrm{g}^{-1}$ at $\mathrm{pH}$. The introduction of iron into the biopolymer matrix increases by four times the sorption uptake of the chitosan; the individual sorption capacity of iron (into the composite) was calculated as $30.9 \mathrm{mg} \mathrm{Nd} / \mathrm{g}$ Fe. The experimental results of the columns were fitted adequately using the Thomas model. As an approach to Nd-Fe-B permanent magnets effluents, a synthetic dilute effluent was simulated at $\mathrm{pH} 4$, in order to evaluate the selectivity of the sorbent material; the overshooting of boron in the column system confirmed the higher selectivity toward neodymium ions. The elution step was carried out using MilliQ-water with the $\mathrm{pH}$ set to 3.5 (dilute $\mathrm{HCl}$ solution).
\end{abstract}

Keywords: boron; chitosan; iron(III) hydroxide; neodymium; sorption

\section{Introduction}

Rare earth elements (REEs) are critical due to their importance for many technological applications. The greater reserves of REEs are located in China; being the main world producer (since the 1990s it has been producing roughly $90 \%$ of the world's supply). REEs are massively used in the manufacturing of high-technology devices; the growing demand of the last decade has forced the mining industry of the European Union to search for new mineral sources outside of China (in order to reduce the strong dependence to this country). Additionally, the popular concept of "urban mining" has been generalized in all European countries over the last five years: society is recognizing that resources contained in wastes should be recovered and reused as much as possible [1].

REEs are distributed in moderated concentration in the earth's crust; the term "rare" originated from the difficult isolation processes on their discovery. Their abundance follows the Oddo-Harking 
rules: elements with even-atomic number are more stable and more abundant than adjacent odd-atomic elements [2,3]. The most abundant REEs in the earth crust are yttrium $\left(28-70 \mathrm{mg} \cdot \mathrm{kg}^{-1}\right)$ and cerium $\left(20-70 \mathrm{mg} \cdot \mathrm{kg}^{-1}\right)$ and the less abundant is thulium $\left(0.2-1.0 \mathrm{mg} \cdot \mathrm{kg}^{-1}\right)$. Special attention must be paid to neodymium $(\mathrm{Nd})$, which is a key element in the high-tech industries and its applications include the manufacturing of the high strength permanent magnets (Nd-Fe-B), the fabrication of electrical motors for hybrid vehicles, and wind turbine generators [4].

Although the concentration of $\mathrm{Nd}$ in the earth's crust is moderate $\left(12-41.5 \mathrm{mg} \cdot \mathrm{kg}^{-1}\right)$, it is also considered as a critical element due to the possible shortage in Chinese export to the EU and USA $[5,6]$. Therefore, the development of novel technologies for recycling and recovery of neodymium is an important task for government authorities. Currently, there is no a simple method for $\mathrm{Nd}$ separation from aqueous effluents. Nevertheless, several methodologies have been used for metal removal from aqueous solutions, such as chemical precipitation $[7,8]$, electrochemical treatment $[9,10]$, membrane technology [11,12], solvent extraction [13], ion-exchange [14,15], and biosorption [16-19].

Recently, our research group [20] suggested liquid-liquid extraction technique with Cyanex-272 and Cyanex- 572 as a good alternative for $\mathrm{Nd}$ separation from waste magnets effluents. This process is particularly useful and efficient for the treatment of wastewaters with high metal concentrations; otherwise, it could not be cost-effective for separating traces of metals, due to the involvement of large amounts of organic solvents and a further step for eluent treatment.

Biosorption could be regarded as the most suitable and economical method for recovering metal ions from dilutes effluents [21,22]. Furthermore, the designing of sorbents is crucial for reaching a high performance; the combination of several reactive groups may improve the stability of the resulting material and improve the removal uptake. To achieve this goal, a composite consisting of chitosan and iron(III) hydroxide [ChiFer(III)] was manufactured (in-situ) and evaluated for Nd sorption from aqueous solutions. Previous studies [23] have reported the use of ChiFer(III) material for boron removal from Mediterranean seawater, the sorbent is stable for several sorption-desorption cycles and can be used under conditions with high ion-strength (i.e., seawater); this information is advantageous for the treatment of waste magnet effluents (e.g., Nd-Fe-B).

In comparison with heavy metals, the literature for REEs recovery through the sorption process is still scarce. Several authors have reported the possibility of using biopolymer-based materials; e.g., Wang et al. [24] evaluated the performance of calcium alginate for $\mathrm{Nd}$ sorption, and Galhoum et al. [25] used cysteine-functionalized chitosan magnetic nano-based particles for removal of light and heavy rare earth elements from aqueous solutions: cationic species La(III), $\mathrm{Nd}(\mathrm{III})$, and $\mathrm{Yb}(\mathrm{III})$ can be sorbed by a combination of chelating and anion-exchange mechanisms; and the thermodynamic constants demonstrated the spontaneous and endothermic nature of sorption. Additionally, Zhao et al. [26,27] synthesized two innovative materials based on: i) EDTA-cross-linked $\beta$-cyclodextrin (EDTA- $\beta$-CD); and ii) polyethylenimine-cross-linked cellulose nanocrystals (PEI-CNC). The sorbents were demonstrated to be selective for $\mathrm{Eu}(\mathrm{IIII})$ and $\mathrm{Er}(\mathrm{III})$ recovery from waters, respectively (i.e., the selectivity of EDTA- $\beta-\mathrm{CD}$ follows: Eu(III) over Ce(III) and $\mathrm{La}(\mathrm{III})$; and PEI-CNC follows: $\mathrm{Er}(\mathrm{III})$ over $\mathrm{La}(\mathrm{III})$ and $\mathrm{Eu}(\mathrm{III})$ ).

Chitosan is a copolymer of glucosamine and $N$-acetyl-D-glucosamine linked by $\beta(1 \rightarrow 4)$ glycosidic bonds [28,29]; its applications are derived from its easy availability (as a renewable resource) and its easy transformation into different configurations: chitosan is considered as the second most abundant biopolymer in the environment after cellulose. This study reports the preparation of chitosan-based composite to improve the handling of $\mathrm{Fe}(\mathrm{OH})_{3}$ as sorbent to recover neodymium in a continuous system. The regeneration of the ChiFer(III) material was evaluated with dilute $\mathrm{HCl}$ solution (demineralized water at $\mathrm{pH} 3.5$ ), and the Thomas model [30] was used to fit the experimental data. 


\section{Materials and Methods}

\subsection{Materials}

Neodymium solutions were prepared using $\mathrm{Nd}\left(\mathrm{NO}_{3}\right)_{3} \cdot 6 \mathrm{H}_{2} \mathrm{O}$ (molecular weight $438.35 \mathrm{~g} \cdot \mathrm{mol}^{-1}$ ) provided by Sigma-Aldrich (St. Louis, MO, USA). Iron(III) chloride hexahydrate used for the sorbent preparation was provided by Panreac (Barcelona, Spain). Chitosan was supplied by Aber Technologies (Lannilis, France), and its molecular weight $\left(125,000 \mathrm{~g} \cdot \mathrm{mol}^{-1}\right)$ was previously reported by Ruiz et al. [31] using size exclusion chromatography (SEC) coupled with light scattering and refractometry. The degree of acetylation determined by Fourier transform infrared (FTIR) spectroscopy was found to be 0.13 (i.e., the deacetylation degree of chitin is 0.87 ) [32].

\subsection{Preparation of ChiFer(III) Microspheres}

The manufacturing of the sorbent material was slightly improved from that of Demey et al. [23]; the chitosan solution with a concentration of $2.2 \% w / w$, was prepared by dissolving $30 \mathrm{~g}$ of chitosan in $2.2 \% w / w$ acetic acid solution $(1350 \mathrm{~mL})$ and stirring for $5 \mathrm{~h}$. Thirty grams of $\mathrm{FeCl}_{3} \cdot 6 \mathrm{H}_{2} \mathrm{O}$ powder were mixed in $120 \mathrm{~mL}$ of $\mathrm{HCl}$ solution $(0.5 \mathrm{M})$ until complete dissolution. The chitosan solution $(1350 \mathrm{~mL}$, $2.2 \% w / w$ ) was then mixed with the iron(III) solution under vigorous stirring (500 rpm) for $2 \mathrm{~h}$.

The chitosan-iron(III) mixture was added drop-by-drop with a peristaltic pump through a thin nozzle $(\varnothing 2.0 \mathrm{~mm})$ into an aqueous solution of $1 \mathrm{M}$ sodium hydroxide under magnetic stirring to produce microspheres of the ChiFer(III) composite. The resulting beads were kept under stirring for $8 \mathrm{~h}$ at room temperature $\left(25^{\circ} \mathrm{C}\right)$ and were then filtered and washed intensively with distilled water to remove the excess of sodium hydroxide from the surface of the sorbent. To compare the effect of the drying method on the kinetic profiles, wet samples of beads were air-dried in a laboratory oven at $45^{\circ} \mathrm{C}$ (AD beads), and freeze dried (using a LyoQuest-55, Telstar equipment, São Paulo, Brazil) at $218 \mathrm{~K}$ and $0.01 \mathrm{mbar}$ (FD beads). The standard sorbent used in this work was the freeze dried beads with an average diameter of $2.0 \mathrm{~mm}$. The average particle size (Sp) of chitosan was $0.5 \mathrm{~mm}<\mathrm{Sp}<1 \mathrm{~mm}$ (Figure S1 in the supplementary materials section); it was verified through a MASTERSIZER $3000^{\mathrm{TM}}$ equipment from Malvern Instruments Ltd., Worcestershire, UK.

\subsection{Characterization of Sorbents}

\subsubsection{Scanning Electron Microscopy}

The samples were analyzed using a JEOL JSM 7100F field emission scanning electron microscope (JEOL Ltd., Peabody, MA, USA), a specialized high-performance scanning electron microscope (SEM) with low-vacuum, and high-vacuum modes, capable of analyzing samples under pressures of up to $9.4 \times 10^{-4} \mathrm{~Pa}$. The objective lens of the JEOL JSM-7100F does not create a magnetic field around the samples and a high magnification is easily obtained (which improves the study of several types of micro/nano-structures). Thus, magnetic samples can be observed and analyzed without restriction. The microscope is also equipped with an Energy Dispersive X-ray (EDX) spectrometer (INCA 250, Oxford instruments, Oxford, UK) for chemical analysis.

The sorbent samples were analyzed before and after sorption of neodymium from aqueous solutions; EDX-analysis technique was used to detect the main elements present at the surface of the sorbent particles.

\subsubsection{FTIR Analyses}

Fourier transform infrared (FTIR) analyses were performed using a BRUKER IFS 66 FTIR spectrophotometer (Bruker Optik $\mathrm{GmbH}$, Ettlingen, Germany) equipped with a reflection diamond accessory (platinum ATR), and the spectra were recorded in the range of $4000-400 \mathrm{~cm}^{-1}$ with a sample amount of $2 \mathrm{mg}$ of ChiFer(III). 


\section{4. $p H$ Effect}

The study of $\mathrm{pH}$-influence on neodymium sorption was performed by mixing $25 \mathrm{~mL}$ of dilute metal solution $\left(9.4 \mathrm{mg} \cdot \mathrm{L}^{-1}\right.$; i.e., $\left.0.07 \mathrm{mmol} \cdot \mathrm{L}^{-1}\right)$ with $25 \mathrm{mg}$ of sorbent (i.e., sorbent dosage, $\mathrm{SD} 1 \mathrm{~g} \cdot \mathrm{L}^{-1}$ ) in $50 \mathrm{~mL}$ polyethylene flasks. Proton concentration was adjusted using $0.1 \mathrm{M} \mathrm{HCl}$ or $0.1 \mathrm{M} \mathrm{NaOH}$ (as required); the evaluated range was set at $\mathrm{pH}$ 1-6 (to prevent metal precipitation in all experimental series) and the stirring speed was set at $150 \mathrm{rpm}$ at $20{ }^{\circ} \mathrm{C}$, using an agitator Rotabit, J.P. Selecta (Barcelona, Spain). After $72 \mathrm{~h}$ of agitation, the final $\mathrm{pH}$ was measured, and $5 \mathrm{~mL}$ of solution was filtered and analyzed with 4100 MP-AES instrument (Microwave plasma-atomic emission spectrometer from Agilent technologies, Melbourne, Australia) at the wavelength of $430.35 \mathrm{~nm}$ (for neodymium detection).

\subsection{Equilibrium Sorption}

Sorption isotherms were obtained by mixing a known volume of solution $(25 \mathrm{~mL})$ at different metal concentrations at selected $\mathrm{pH} 4$ and a fixed mass of sorbent $\left(25 \mathrm{mg}\right.$; i.e., SD $\left.1 \mathrm{~g} \cdot \mathrm{L}^{-1}\right)$. After $72 \mathrm{~h}$ of contact, the pHs of the solutions were measured and the initial and equilibrium metal concentrations were systematically determined using 4100 MP-AES equipment (Agilent technologies, Melbourne, Australia).

The Langmuir, the Freundlich, and the Sips equations were used to describe the experimental sorption isotherm data [33-36]:

$$
\begin{gathered}
\mathrm{q}=\frac{\mathrm{q}_{\mathrm{max}} \mathrm{b} C_{\mathrm{eq}}}{1+\mathrm{bC}_{\mathrm{eq}}} \\
\mathrm{q}=\mathrm{K}_{\mathrm{F}} \mathrm{C}_{\mathrm{eq}}^{1 / \mathrm{n}} \\
\mathrm{q}=\frac{\mathrm{q}_{\mathrm{max}} \mathrm{K}_{\mathrm{S}} \mathrm{C}_{\mathrm{eq}}^{1 / \mathrm{ns}}}{1+\mathrm{K}_{\mathrm{S}} \mathrm{C}_{\mathrm{eq}}^{1 / \mathrm{ss}}}
\end{gathered}
$$

where $\mathrm{q}$ is the amount of sorbed metal per gram of sorbent at equilibrium $\left(\mathrm{mg} \cdot \mathrm{g}^{-1}\right)$, qmax is the maximum adsorption capacity of the sorbent $\left(\mathrm{mg} \mathrm{g}^{-1}\right)$, and Ceq is the equilibrium concentration of the solution $\left(\mathrm{mg} \cdot \mathrm{L}^{-1}\right)$. In the Langmuir model (equation 1$)$, $\mathrm{b}$ is related to the energy of adsorption $\left(\mathrm{L} \cdot \mathrm{mg}^{-1}\right)$, whereas KF and $\mathrm{n}$ are the Freundlich adsorption constants, indicative of the relative capacity

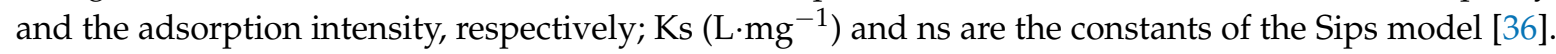
The experiments of equilibrium studies were performed in duplicate to ensure the accuracy of the results (the relative standard deviation obtained was in the order of $\pm 5 \%$ ).

\subsection{Influence of Contact Time}

The uptake kinetics experiments were performed by adding (under continuous stirring) a known amount of sorbent (SD $0.5 \mathrm{~g} \cdot \mathrm{L}^{-1}$ ) to $500 \mathrm{~mL}$ of metal solution (i.e., $10-20 \mathrm{mg} \cdot \mathrm{L}^{-1}$ ) at $\mathrm{pH} 4$. Aliquots of solution were withdrawn at different times and filtered over $72 \mathrm{~h}$ of contact with the beads. The residual concentration was determined by the 4100 MP-AES instrument. The kinetic profiles were compared by using sorbent beads under the same conditioning (freeze-dried beads; Ø $2.0 \mathrm{~mm}$ ). The models such as PFORE and PSORE (pseudo-first order and pseudo-second order rate equations) were evaluated to fit the experimental data; the contribution of the resistance to intraparticle diffusion was evaluated by the equation of Weber and Morris, [37]:

Pseudo-first order rate equation (PFORE) [38,39]:

$$
\frac{\mathrm{dq}_{\mathrm{t}}}{d t}=\mathrm{K}_{1}\left(\mathrm{q}_{1}-\mathrm{q}_{\mathrm{t}}\right)
$$


Pseudo-second order rate equation (PSORE) [40]:

$$
\frac{\mathrm{dq}_{\mathrm{t}}}{\left(\mathrm{q}_{\mathrm{eq}}-\mathrm{q}_{\mathrm{t}}\right)^{2}}=\mathrm{K}_{2} d t
$$

where $\mathrm{q}_{\mathrm{eq}}$ is the equilibrium sorption capacity $\left(\mathrm{mg} \cdot \mathrm{g}^{-1}\right), \mathrm{q}_{\mathrm{t}}$ is the sorption capacity $\left(\mathrm{mg} \cdot \mathrm{g}^{-1}\right)$ at any time $\mathrm{t}(\mathrm{min})$, and $\mathrm{k}_{2}$ is the pseudo-second order rate constant $\left(\mathrm{g} \cdot \mathrm{mg}^{-1} \cdot \mathrm{min}^{-1}\right)$. The parameters $\mathrm{q}_{\mathrm{eq}}$ and $\mathrm{k}_{2}$ are pseudo-constants depending on the experimental conditions.

Equation of Weber and Morris, [37]:

$$
\mathrm{q}_{\mathrm{t}}=\mathrm{K}_{\mathrm{p}} \mathrm{t}^{1 / 2}+\mathrm{C}
$$

where $C$ is the intercept, and $K_{p}$ is the intraparticle diffusion rate constant.

\subsection{Dynamic Column Testing}

The applicability of a dynamic system was tested for evaluating the sorption performance of ChiFer(III) material on neodymium sorption. The glass columns (i.d., $\varnothing 1.8 \mathrm{~cm}$ ) were filled with hydrated beads (Ø $2.0 \mathrm{~mm}$; $2.4 \mathrm{~g}$ in d.w.) until a bed depth of $23 \mathrm{~cm}$ (i.e., bed-volume: $58.53 \mathrm{~mL}$ ). In order to avoid a poor arrangement of the packed-bed, the sorbent was carefully introduced into the columns from the top in a water suspension (typically $1 \mathrm{~g} \cdot \mathrm{L}^{-1}$ ). Then, the bottom of the column was kept open (over $2 \mathrm{~h}$ ) to evacuate the water content.

The metal solution was delivered by up-flow at $20^{\circ} \mathrm{C}$ using a peristaltic pump at a flow rate of 0.01 and $0.02 \mathrm{~L} \cdot \mathrm{h}^{-1}$ (i.e., superficial velocity: $3.77 \times 10^{-2} \mathrm{~m} \cdot \mathrm{h}^{-1}$ and $8.01 \times 10^{-2} \mathrm{~m} \cdot \mathrm{h}^{-1}$ respectively). The tests were performed at $\mathrm{pH} 4.5$ and inlet concentration of $10 \mathrm{mg} \cdot \mathrm{L}^{-1}$. After saturation, the packed-bed was eluted upward using dilute $\mathrm{HCl}$ solution (demineralized water at $\mathrm{pH}$ 3.5) and a flow rate of $0.01 \mathrm{~L} \cdot \mathrm{h}^{-1}$. Samples of $5 \mathrm{~mL}$ were periodically collected for analyzing during sorption and desorption steps using an automatic fraction collector (Gilson FC-203 B, Dunstable, UK).

It is noteworthy that, the breakthrough curve allows the behavior of recovered metal into the sorbent bed to be represented; it is typically plotted as the ratio of effluent concentration to inlet concentration $\left(C_{t} / C_{0}\right)$ as a function of the operational time $t$, or also as a function of the ratio volume of the influent/volume of the packed-bed (so called bed-volume, BV). The breakthrough and the exhaustion points were set as $C_{t} / C_{0}=0.05$ and $C_{t} / C_{0}=0.95$, respectively. The experimental sorption capacity can be obtained from Equation (7):

$$
\mathrm{q}_{\text {exp }}=\int_{0}^{\mathrm{V}_{\text {total }}} \frac{\left(\mathrm{C}_{0}-\mathrm{C}_{\mathrm{t}}\right)}{\mathrm{m}} \mathrm{dV}
$$

The Thomas model equation [30] was used for describing the theoretical performance of the columns due to its simplicity and adequate accuracy in predicting breakthrough curves. The model can be represented by the following equation for favorable sorption process [41]:

$$
\frac{\mathrm{C}_{\mathrm{t}}}{\mathrm{C}_{0}}=\frac{1}{1+\exp \left[\mathrm{K}_{\mathrm{T}}\left(\mathrm{q}_{\mathrm{T}} \mathrm{m}-\mathrm{C}_{0} \mathrm{~V}\right) / \mathrm{Q}\right]}
$$

where $\mathrm{K}_{\mathrm{T}}$ is the Thomas rate constant $\left(\mathrm{L} \cdot \mathrm{h}^{-1} \cdot \mathrm{mg}^{-1}\right)$, $\mathrm{m}$ is the mass of sorbent $(\mathrm{g}), \mathrm{Q}$ is the volumetric flow rate $\left(\mathrm{L} \cdot \mathrm{h}^{-1}\right), \mathrm{V}$ is the volume of the solution into the column $(\mathrm{L}), \mathrm{C}_{\mathrm{t}}$ is the metal concentration $\left(\mathrm{mg} \cdot \mathrm{L}^{-1}\right)$, and $\mathrm{q}_{\mathrm{T}}$ is the Thomas sorption capacity $\left(\mathrm{mg} \cdot \mathrm{g}^{-1}\right)$. The constants of the non-linearized form were obtained by origin 9.0 software (OriginLab Inc., Northampton, MA, USA, 2012).

In addition, a selectivity study was developed by using a binary system (in columns) with an equimolar solution of neodymium and boron $\left(0.1 \mathrm{mmol} \cdot \mathrm{L}^{-1}\right)$, in order to approach the real effluent of permanent magnets (Nd-Fe-B). Sorption systems are usually employed as polishing steps at $\mathrm{pH}$ 4-6 
(as a complement of traditional physical-chemical techniques); therefore metal concentrations are very dilute at these operating conditions, especially iron concentration which is almost negligible and it was not considered in this study.

The separation coefficients of neodymium and boron $\left(\mathrm{R}_{\mathrm{Nd} / \mathrm{B}}\right)$ were calculated as follows and plotted versus the bed-volume [42]:

$$
\begin{gathered}
\mathrm{Kd}_{i}=\int_{0}^{\mathrm{V}_{\text {total }}} \frac{\left(\mathrm{C}_{0}-\mathrm{C}_{\mathrm{t}}\right)}{\mathrm{C}_{0} \mathrm{~m}} \mathrm{dV} \\
\mathrm{R}_{\mathrm{Nd} / \mathrm{B}}=\frac{\mathrm{Kd}_{\mathrm{Nd}}}{\mathrm{Kd}_{\mathrm{B}}}
\end{gathered}
$$

where $R_{N d / B}$ is the separation coefficient of $\mathrm{Nd}$ and $\mathrm{B} ; \mathrm{K}_{\mathrm{d}}$ is the distribution coefficient $\left(\mathrm{L} \cdot \mathrm{g}^{-1}\right) ; \mathrm{C}_{\mathrm{o}}$ is initial metal concentration $\left(\mathrm{mg} \cdot \mathrm{L}^{-1}\right) ; \mathrm{C}_{\mathrm{t}}$ is the metal concentration at the time $\mathrm{t}\left(\mathrm{mg} \cdot \mathrm{L}^{-1}\right) ; \mathrm{m}$ is the mass of the sorbent $(\mathrm{g}) ; \mathrm{V}$ is the volume of the solution passed into the column $(\mathrm{L})$.

\section{Results and Discussion}

\subsection{Characterization of Sorbent}

\subsubsection{Scanning Electron Microscopy}

SEM micrographs were performed for exploring the topography of the sorbent surface, as well as to examine the external and internal structure of the beads configuration. Figure 1a shows the spherical shape of the standard freeze-dried material (average diameter, $\varnothing 2.0 \mathrm{~mm}$ ); some cavities are found around the entire external surface, which is an indication of the easy accessibility for sorbate molecules into the volume of the beads. The images performed on the cross-section area, corroborate that the internal topography is relatively open (Figure 1b); this is a relevant feature for enhancing the diffusion phenomenon.

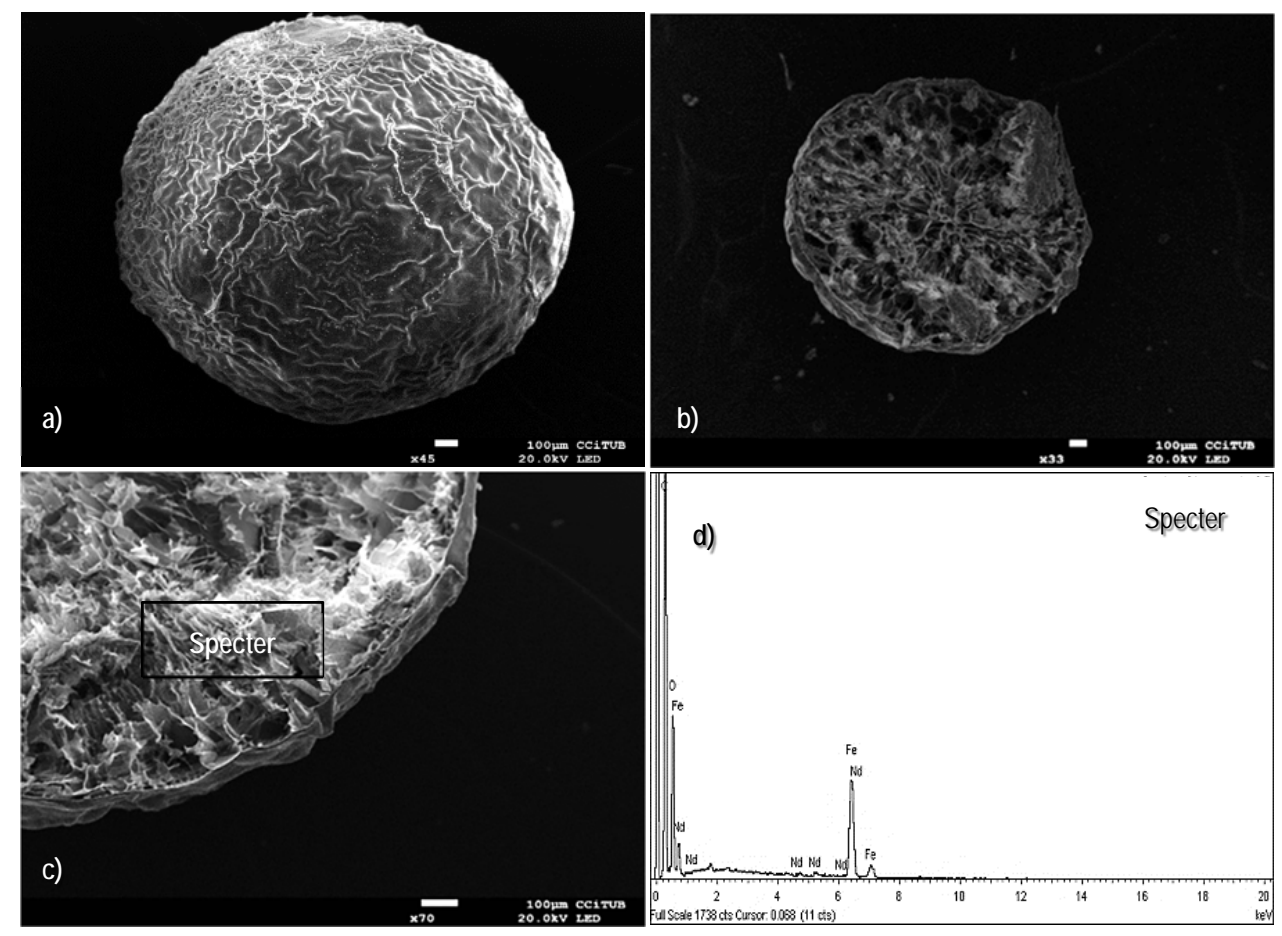

Figure 1. Scanning electron microscopy (SEM) images of the freeze dried (FD) sorbent. (a) External surface. (b) Cross-section area. (c,d) Energy dispersive X-ray (EDX) analysis of the cross-section area of the beads. 
EDX-analyses on different zones of the cross-section area (Figure 1c,d) suggest that the main elements of the composite (i.e., oxygen, carbon, and iron) are homogenously distributed in the whole volume of the sorbent. The total amount of iron distributed throughout the dried material was quantified by $4100 \mathrm{MP}-\mathrm{AES}$ technique (a known amount of beads was kept under contact with $10 \mathrm{M}$ $\mathrm{HNO}_{3}$ solution over $10 \mathrm{~h}$ until complete digestion of the organic and mineral components): it was found to be $330 \mathrm{mg}$ of iron per gram of ChiFer(III).

The micrographs presented in Figure 1 are in complete agreement with the previous findings reported by Demey et al. [23]; the manufacturing of iron(III) hydroxide through the in-situ coagulation of chitosan solution provides an innovative technique for immobilization of active mineral materials over a polymeric and well distributed network. A second configuration of the sorbent, the so-called xerogel material, was examined for verifying the impact of the drying method on the resulting structure; Figure 2a,b show that the uncontrolled air-drying of the hydrogels leads to shrinkage of the surfaces with depleted performance of mass transfer [43]. The air-dried particles have an average diameter of $0.90 \mathrm{~mm}$; some folds over the entire surface are formed due to water evaporation at ambient pressure conditions, and the cavities or pores (around the folds) appear not to be easy accessible for sorbate ions. Figure $2 c$ shows the cross-section area of the xerogels which differ widely from the freeze-dried beads: it seems to be a closed network; however, the EDX-analysis (Figure 2d) confirmed the content of the main elements, as expected (i.e., oxygen, carbon, and iron).
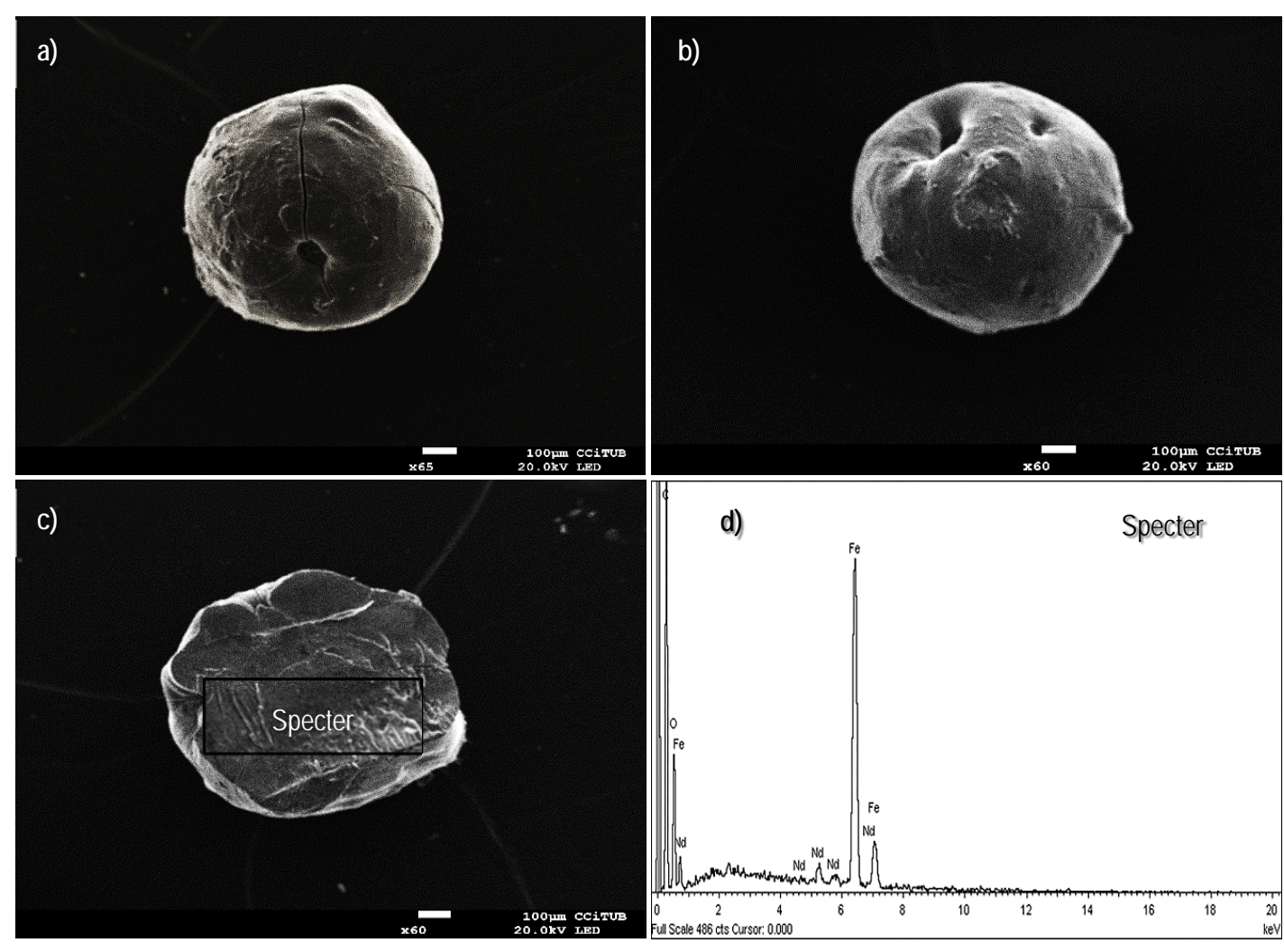

Figure 2. Scanning electron microscopy (SEM) images of the air dried (AD) sorbent. (a) External surface. (b) Cross-section area. (c,d) Energy dispersive X-ray (EDX) analysis of the cross-section area of the beads.

In this work, the freeze-drying method was preferred over the air-drying technique since the resulting beads could provide a network structure with more easy accessibility, and the regular spherical shape of the particles may improve packaging into the fixed bed (improving the mass transfer of the system). According to Borisova et al. [44] a better storage/conservation of the structures of the hydrogels can be performed by a novel technique based on the supercritical conditions of $\mathrm{CO}_{2}$ 
$\left(\mathrm{scCO}_{2}\right)$, nevertheless the freeze-drying technique is less expensive than $\mathrm{scCO}_{2}$ and the resulting dried materials adequately conserve their original structures [45].

Additionally, EDX-analysis were used for examining the cartography on the cross-section area of ChiFer(III) after neodymium removal from aqueous solutions. Figure 3 gives a qualitative representation of the elements contained in the volume of sorbent (such as carbon, oxygen, iron, and neodymium); neodymium appears to be homogenously distributed in the entire volume of the beads, which is useful information for interpreting the kinetic data.
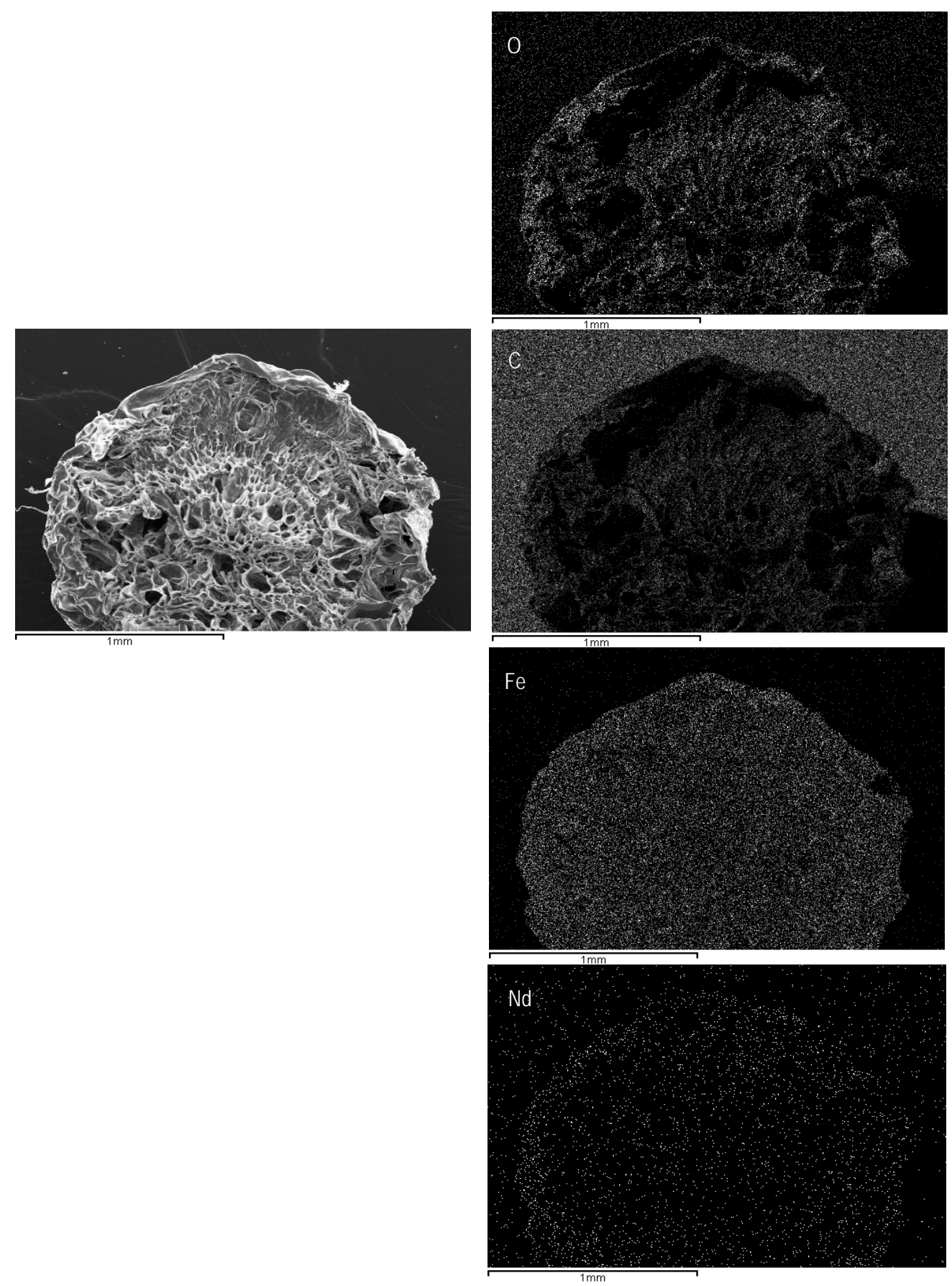

Figure 3. Distribution of the main components on the cross-section area of the ChiFer(III) material after sorption. (Right side: Original structure; left side: Distribution of O: Oxygen; C: Carbon; Fe: Iron; Nd: Neodymium). 
Figure S2 (in the Supplementary Materials Section) shows the characteristics peaks (FTIR analyses) of the ChiFer(III) sorbent; the broad band centered at $3000-3600 \mathrm{~cm}^{-1}$ is due mainly to the hydroxyl groups (stretching vibrations of $\mathrm{C}-\mathrm{OH}$ and $\mathrm{Fe}-\mathrm{OH}$ ) and to the extension vibration of $\mathrm{N}-\mathrm{H}$ group of the primary amine $\left(-\mathrm{NH}_{2}\right)$ of chitosan [42]. The band at $2885 \mathrm{~cm}^{-1}$ is usually assigned to symmetric $-\mathrm{CH}_{2}$ groups $[28,46]$; the bands at $1408 \mathrm{~cm}^{-1}$ and $1022 \mathrm{~cm}^{-1}$ are attributed to the $\mathrm{C}-\mathrm{O}-\mathrm{C}$ and to the C-O stretching vibrations, respectively $[25,47]$, and the band centered at $1630 \mathrm{~cm}^{-1}$ is attributed to the stretching vibration of $\mathrm{C}=\mathrm{O}$ (carboxylate groups of polysaccharides, [42]). The peak around the band at $898 \mathrm{~cm}^{-1}$ was attributed by Wang et al. [28] to the $\beta$-D-glucose unit of chitosan. The absorption band at $586 \mathrm{~cm}^{-1}$ is due to the $\mathrm{Fe}-\mathrm{O}$ stretching vibration of $\mathrm{Fe}_{3} \mathrm{O}_{4}$, Shinde et al. [48] found that this band is specially shifted with an increase of $\mathrm{Nd}$ concentration (in contact with nickel ferrites material); in this study, the dilute concentrations of neodymium solutions $\left(<0.01 \mathrm{~mol} \cdot \mathrm{L}^{-1}\right)$ did not lead to verification of this finding.

\section{2. $p H$ Effect}

The $\mathrm{pH}$ is one of the most important parameters in the sorption process. The proton concentration influences metal speciation which impacts on metal/sorbent interactions, affecting the sorption performance. The plot of metal distribution of neodymium and iron species at dilute concentrations $\left(1 \mathrm{mmol} \cdot \mathrm{L}^{-1}\right)$ is represented in the Supplementary Materials Section (Figure S3); the experiments were conducted to avoid the precipitation phenomenon of neodymium.

Sorption performances of ChiFer(III) were compared with raw chitosan particles in the range of $\mathrm{pH} 1$ to 6 (Figure 4a); at very acidic conditions the sorption is not favored since at $\mathrm{pH}$ below $\mathrm{pH} 3$ some traces of iron are released into the solution, from $\mathrm{pH}<2$ the sorbents are completely dissolved (Figure S4), due to the natural hydrolysis of chitosan in acidic medium [49]. The best results and stability were obtained in the range of $\mathrm{pH} 4-6$; the material is sufficiently stable and the introduction of iron into the chitosan matrix may enhance the sorption capacity of raw chitosan: at $\mathrm{pH} 5$ the ChiFer(III) material increased by two times the removal achieved by chitosan particles (i.e., $98.8 \%$ and $49.3 \%$ respectively).

Figure $4 \mathrm{~b}, \mathrm{c}$ show the $\mathrm{pH}$ variation after metal sorption: when the initial $\mathrm{pH}$ was in the range 3-4, the equilibrium $\mathrm{pH}$ increased up to 4.4-5.0; for initial values of $\mathrm{pH} 5.0-6.5$ the equilibrium $\mathrm{pH}$ tends to stabilize around $\mathrm{pH}$ 4.8-5.5. This type of "buffering effect" can be attributed to the acid- basic properties of chitosan; according to Sorlier et al. [50], the pKa of chitosan depends on parameters such as the deacetylation degree and the ionization extent of the polymer. The pKa for standard samples varies between 6.3 and 6.8; when the solution $\mathrm{pH}$ is below the $\mathrm{pKa}$, chitosan tends to bind protons increasing the $\mathrm{pH}$. Hence, at low $\mathrm{pH}$ values, the coordinating atoms in the sorbent (amino groups) are protonated which in contact with $\mathrm{Nd}$ species lead to repulsive electrostatic forces, limiting the sorption onto the sorbents materials. 
a)

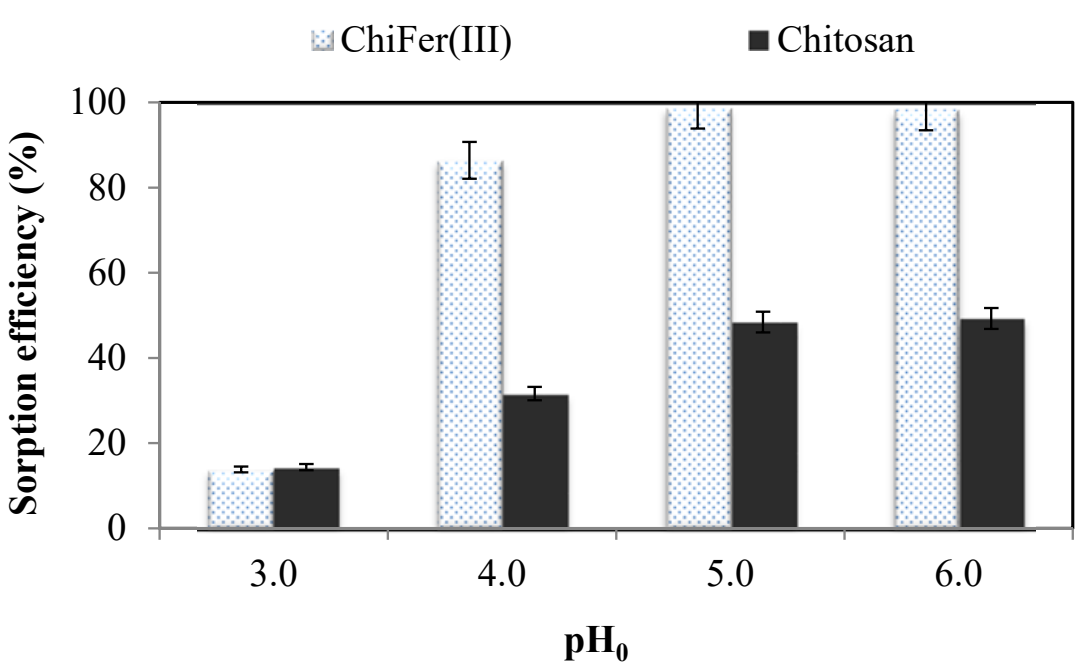

b)
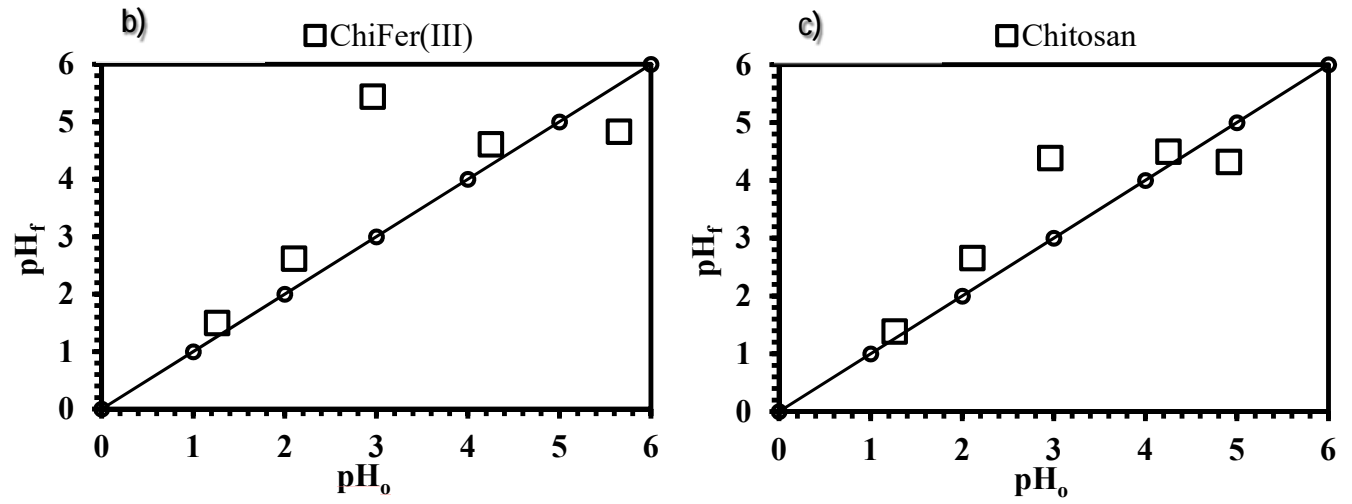

Figure 4. Influence of $\mathrm{pH}$ on neodymium removal. (a) Sorption efficiency. (b) Variation in $\mathrm{pH}$ using ChiFer(III) as sorbent. (c) Variation in $\mathrm{pH}$ using chitosan as sorbent. (T: $20^{\circ} \mathrm{C}$; sorbent dosage, SD: $1 \mathrm{~g} \cdot \mathrm{L}^{-1}$; agitation speed: $150 \mathrm{rpm}$; contact time: $\left.72 \mathrm{~h} ; \mathrm{C}_{0}: 9.4 \mathrm{mg} \cdot \mathrm{L}^{-1}\right)$.

\subsection{Equilibrium Studies}

Isotherms are critical in optimizing sorption processes since they help to describe the distribution of the sorbate between the liquid and solid phases at equilibrium. The correlation of data by theoretical or empirical equations is essential for the practical design of the sorption systems; different models have been proposed in the literature including Langmuir, Freundlich, and Sips equations, nevertheless, the fit of the experimental data does not mean that the principles of the models are verified, although it leads to a better interpretation of the sorption mechanism.

Figure 5 shows the impact of the metal concentration on the sorption uptake; increasing the neodymium concentration increases the metal removal progressively until a saturation plateau is reached (beyond which no further sorption can take place) [51]. At dilute metal concentrations (i.e., $5 \mathrm{mg} \cdot \mathrm{L}^{-1}$ ) the sorbents allow removing of more than $60 \%$ of Nd; it meets the characteristics of a typical favorable sorption profile (asymptotic shape of the isotherm is consistent with the Langmuir equation), making these materials interesting for the treatment of dilute effluents. 


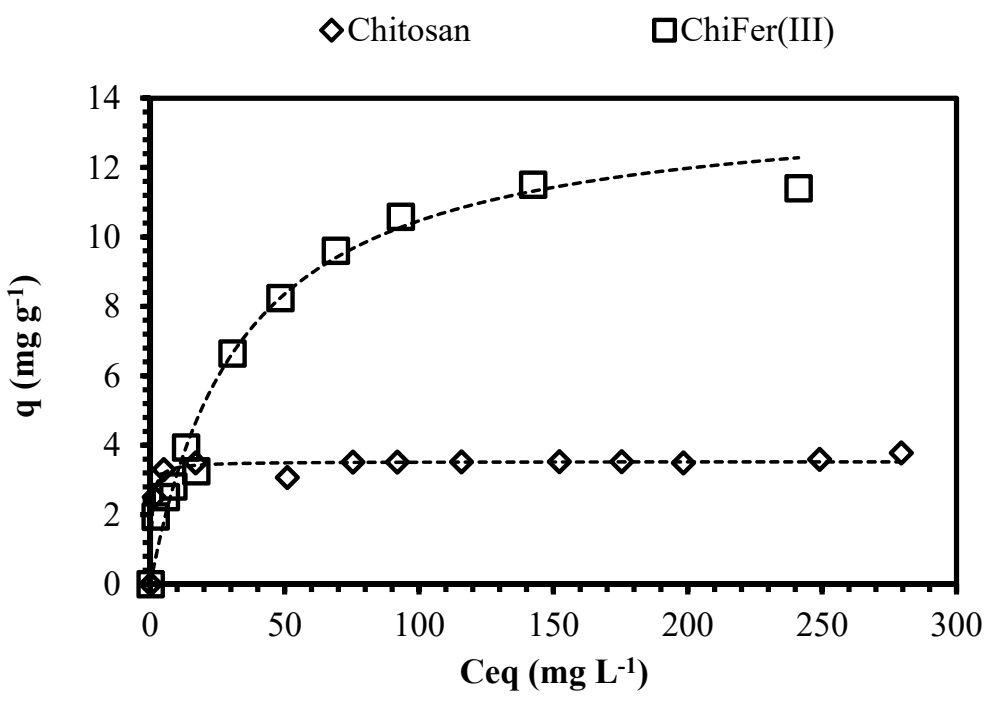

Figure 5. Isotherm plots for neodymium removal. (Solid line: Langmuir model; $\mathrm{T}$ : $20{ }^{\circ} \mathrm{C}$; sorbent dosage, SD: $1 \mathrm{~g} \cdot \mathrm{L}^{-1}$; agitation speed: $150 \mathrm{rpm}$; contact time: $72 \mathrm{~h} ; \mathrm{pH}: 4 ; \mathrm{C}_{0}: 5-400 \mathrm{mg} \cdot \mathrm{L}^{-1}$ ).

Table 1 shows the fitting values of the Langmuir, Freundlich, and Sips models; the experimental data were fitted with Langmuir equations with better accuracy. Sips equation is a common adaptation of the Langmuir-Freundlich models; values for $1 / \mathrm{ns}$ close to zero are generally associated with heterogeneous sorbents, while values closer to 1.0 correspond to sorbents with relatively homogeneous binding sites [36]. Sorption capacity of ChiFer(III) is almost four times higher than raw chitosan particles, it is consistent with the values obtained in the $\mathrm{pH}$ study: the introduction of iron into the composite increases the removal of $\mathrm{Nd}$ (the maximum sorption capacities obtained are $3.5 \mathrm{mg} \cdot \mathrm{g}^{-1}$ and $13.8 \mathrm{mg} \cdot \mathrm{g}^{-1}$ for chitosan and ChiFer(III) respectively); taking into account that iron content in the composite is $0.33 \mathrm{~g}$ per gram of dried ChiFer(III), the contribution of iron is calculated as $30.9 \mathrm{mg}$ $\mathrm{Nd} / \mathrm{g} \mathrm{Fe}$, which is very close to the value reported by Tu et al. [4] using magnetic iron oxide $\left(\mathrm{Fe}_{3} \mathrm{O}_{4}\right)$ particles as sorbent (Table 2).

Table 1. Langmuir, Freundlich, and Sips constants of ChiFer(III) and chitosan particles.

\begin{tabular}{lcccccccccccc}
\hline \multicolumn{2}{c}{ Experimental } & \multicolumn{3}{c}{ Langmuir } & \multicolumn{3}{c}{ Freundlich } & \multicolumn{3}{c}{ Sips } \\
\hline Sorbent & $\begin{array}{c}\mathrm{q}_{\text {exp }} \\
\left(\mathrm{mg}^{-1} \mathrm{~g}^{-1}\right)\end{array}$ & $\begin{array}{c}\mathrm{q}_{\mathrm{max}} \\
\left(\mathrm{mg}^{-1} \mathrm{~g}^{-1}\right)\end{array}$ & $\begin{array}{c}\mathrm{b} \\
\left(\mathrm{L} \cdot \mathrm{mg}^{-1}\right)\end{array}$ & $\mathrm{r}^{2}$ & $\begin{array}{c}\mathrm{K}_{\mathrm{F}} \\
\left(\mathrm{mg}^{1-1 / \mathrm{n}}\right. \\
\left.\mathrm{g}^{-1} \cdot \mathrm{L}^{1 / \mathrm{n}}\right)\end{array}$ & $\mathrm{n}$ & $\mathrm{r}^{2}$ & $\begin{array}{c}\mathrm{q}_{\mathrm{max}} \\
\left(\mathrm{mg}^{-1} \mathrm{~g}^{-1}\right)\end{array}$ & $\begin{array}{c}\mathrm{Ks} \\
\left(\mathrm{L} \cdot \mathrm{mg}^{-1}\right)\end{array}$ & $\mathrm{ns}$ & $\mathrm{r}^{2}$ \\
\hline Chitosan & 3.77 & 3.54 & 1.91 & 0.971 & 2.78 & 20.44 & 0.957 & 3.51 & 1.75 & 0.80 & 0.966 \\
ChiFer(III) & 11.51 & 13.76 & 0.03 & 0.973 & 1.65 & 2.63 & 0.922 & 13.80 & 0.03 & 1.00 & 0.969 \\
\hline
\end{tabular}

Moreover, the configuration of the material under the form of spherical beads contributes to improving the handling of the sorbent for a fixed packed (column) system; it avoids the typical operational difficulties found for non-regular particles (as chitosan): (i) high head-loss and clogging effect; (ii) diffusional problems; (iii) reduction of the mass transfer performance due to a non-uniform arrangement of the bed in the column. The findings can be compared with those obtained by Wang et al. [24]; the authors evaluated calcium alginate under beads configuration and a novel hybrid gel (ALG-PGA: prepared from calcium alginate (ALG) and y-poly glutamic acid (PGA)); the results demonstrated that the introduction of PGA molecules into the alginate matrix, significantly enhanced the sorption capacity of the final sorbent. Thus, polymeric structures may improve the management of active materials and according to the functional groups may contribute to increasing metal uptake. 
Table 2 shows a comparison of the maximum sorption capacities of several sorbents found in the literature; ChiFer(III) has a sorption uptake of the same order of magnitude. Although $\mathrm{SiO}_{2} / \mathrm{CMCH}$ material [42] has a higher performance, the simplicity of the manufacturing process and the hydro-dynamic ability for columns make ChiFer(III) beads a promising sorbent for neodymium removal from aqueous solutions.

Table 2. Comparison of sorption capacities for several sorbents.

\begin{tabular}{lccc}
\hline \multicolumn{1}{c}{ Sorbent } & pH Range & $\begin{array}{c}\text { qmax } \\
\left(\mathbf{m g} \cdot \mathbf{g}^{-\mathbf{1}} \mathbf{)}\right.\end{array}$ & Authors \\
\hline C. colliculosa yeast & 1.5 & 10.0 & Vlachou et al. [52] \\
K. marxianus yeast & 1.5 & 12.0 & Vlachou et al. [52] \\
D. hansenii yeast & 1.5 & 10.0 & Vlachou et al. [52] \\
ChiFer(III) beads & $4.0-5.0$ & 13.8 & This work \\
Cysteine-functionalized chitosan magnetic particles & 6.0 & $15.3-17.1$ & Galhoum et al. [25] \\
Magnetic iron oxide $\left(\mathrm{Fe}_{3} \mathrm{O}_{4}\right)$ & 8.2 & 24.8 & Tu et al. [4] \\
Ion imprinted polymer & $7.0-7.5$ & 35.2 & Guo et al. [53] \\
$\mathrm{SiO}_{2}$ /Carboxymethyl chitosan $(\mathrm{CMCH})$ & 6.9 & 53.0 & Wang et al. [42] \\
\hline
\end{tabular}

\subsection{Influence of Contact Time}

Figure 6 shows the kinetic profiles for sorption of neodymium using freeze-dried beads (FD), air-dried beads (AD), and raw chitosan particles; in the literature, it was reported that the drying procedure may impact on the kinetic profiles [43]. Different techniques have been used for maintaining the original structures of hydrogels after drying. Borisova et al. [44] suggested that drying under supercritical $\mathrm{CO}_{2}$ conditions may improve the storage and lead to conserving the porosity of the manufactured materials (as a consequence, accessibility into active sites is not strongly modified); however it could be cost-expensive (in terms of energy) for drying large amounts of materials (at industrial scale production). In turn, freeze-drying and air-drying techniques (which are easy to operate at large-scale production) were compared in order to evaluate their contribution to the kinetic profiles.

ChiFer(III) beads and chitosan particles have a similar trend, and regardless of the type of drying, three pseudo steps can be considered: (i) an initial fast step that takes around 20 min for chitosan particles and 30-45 min for FD and AD beads (it represents 12\%, 14\%, and 31\% of the total metal sorption using $\mathrm{AD}$, chitosan and FD beads respectively); (ii) a second step which takes 3-6 $\mathrm{h}$ and accounts for an increase of $2 \%-13 \%$; (iii) a third step which accounts for a lesser metal uptake $(<5 \%)$. The difference in metal sorption (of each step) can be explained by the fact that the concentration gradient decreases progressively with the time: at longer contact time, the mass transfer is slower, since the driving force decreases.

It is noteworthy that kinetic uptakes are controlled by several mechanisms, including: (i) bulk diffusion; (ii) external diffusion (also called film diffusion); (iii) intraparticle diffusion; and (iv) reaction rate. Benettayeb et al. [54] pointed out that by maintaining a sufficient agitation speed and avoiding the settling of the sorbent, the contribution to the bulk diffusion could be neglected: this consideration was especially taken into account for performing the kinetic experiments and the system was kept continuously agitated (150 rpm). 

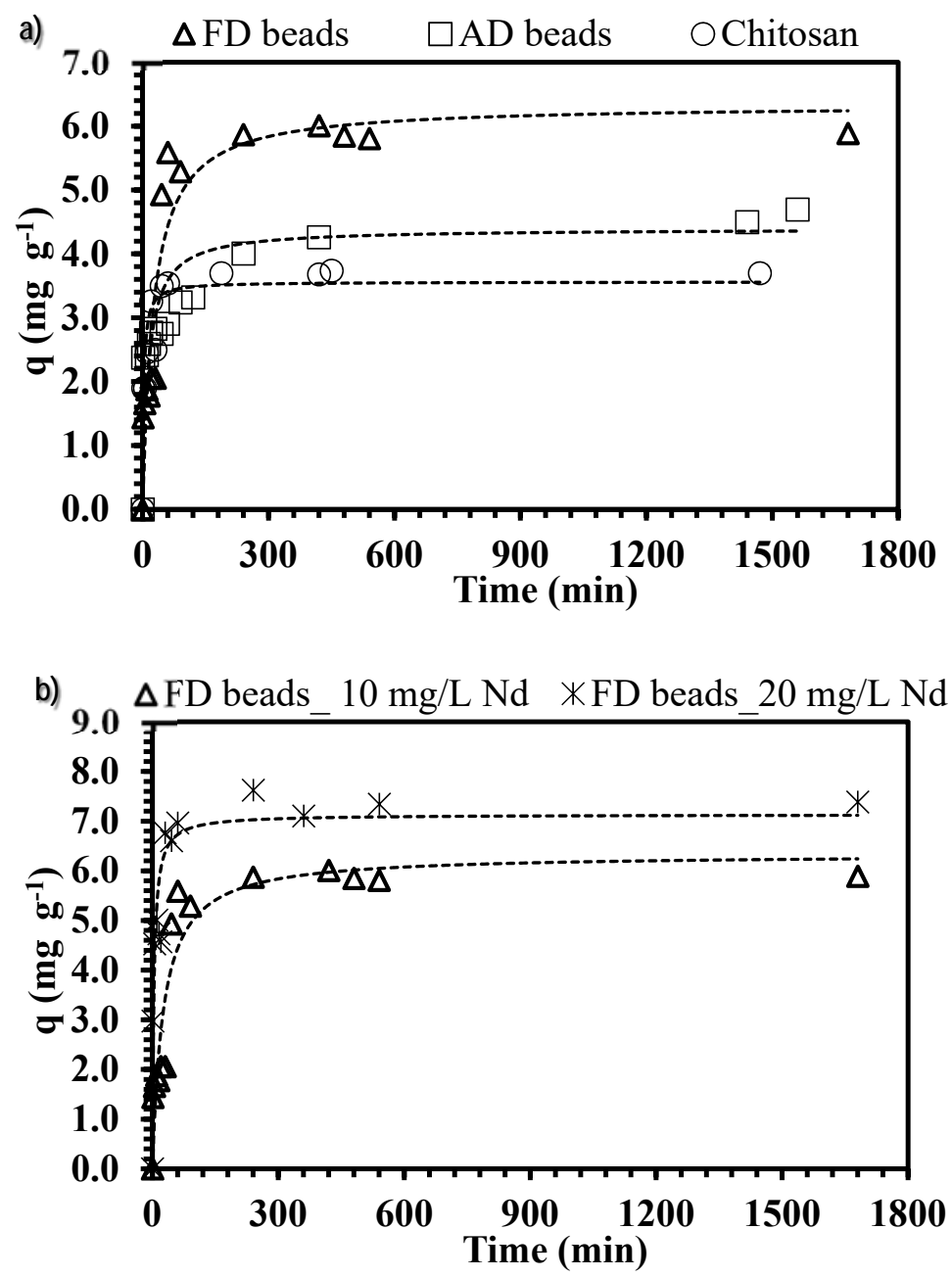

Figure 6. Effect of contact time on ChiFer(III) material performance. (a) Effect of drying method. (b) Effect of initial metal concentration. (Dashed line: Pseudo-second order rate equation (PSORE); $\mathrm{T}$ : $20{ }^{\circ} \mathrm{C}$; sorbent dosage, SD: $0.5 \mathrm{~g} \cdot \mathrm{L}^{-1}$; agitation speed: $150 \mathrm{rpm}$; contact time: $72 \mathrm{~h} ; \mathrm{pH}: 4 ; \mathrm{C}_{0}$ : $\left.10-20 \mathrm{mg} \cdot \mathrm{L}^{-1}\right)$.

As expected (Figure 6a), the time for achieving the equilibrium is shortened for chitosan due to the small particles size $(0.5 \mathrm{~mm}<\mathrm{Sp}<1 \mathrm{~mm})$ which results in more available surface area, impacting on the resistance to the external film diffusion and a greater number of active sites are quickly available. Moreover, the time required for FD is less than for AD beads ( $5 \mathrm{~h}$ for FD and $7 \mathrm{~h}$ for AD); it can be explained by the open structure of the sorbent, produced as a result of the freeze-drying technique, which improves the diffusion and the accessibility of neodymium into the active sites. Table 3 reports the comparison of the experimental sorption capacities at equilibrium with calculated values for both the pseudo-first order and the pseudo-second order rate equation models (PFORE and PSORE); the correlation coefficients confirm a better fitting with PSORE.

Additionally, the simplified equation of Weber and Morris, [37] (W\&M) was tested for evaluating the contribution of the resistance in the intraparticle diffusion. The plots on Supplementary Materials Section (Figure S5) have three slopes (corresponding to the external surface diffusion, intraparticle diffusion, and reaction rate steps), which do not pass through the origin; this is an indication that intraparticle diffusion is not the unique mechanism that controls neodymium removal. Thus, $K_{p}$ values were obtained from the slope of the linear portions of the second phase of the kinetics profiles, these do not show a significant trend (Table 3), but it is evident that the $K_{p}$ value for FD beads is higher than for $\mathrm{AD}$ beads at the same operating conditions (this confirms the easy accessibility and a better 
diffusion is performed into the pores of FD material). Nevertheless, for chitosan particles, the initial slope (attributed to the external diffusion) is considerably steeper than the second step (attributed to the intraparticle diffusion); this verifies that intraparticle diffusion is not only the controlling step of the process.

Table 3. Kinetic parameters of sorbent materials.

\begin{tabular}{|c|c|c|c|c|c|c|c|c|}
\hline \multicolumn{2}{|c|}{ Experimental } & \multicolumn{3}{|c|}{$\begin{array}{c}\text { Pseudo-First Order } \\
\text { Rate Equation (PFORE) }\end{array}$} & \multicolumn{3}{|c|}{$\begin{array}{l}\text { Pseudo-Second Order } \\
\text { Rate Equation (PSORE) }\end{array}$} & \multirow{2}{*}{$\begin{array}{c}\begin{array}{c}\text { Weber and } \\
\text { Morris } \\
\text { Equation } \\
(\mathrm{W} \& \mathrm{M})\end{array} \\
\mathrm{K} \\
\left(\mathrm{Kg} \cdot \mathrm{g}^{-1} \cdot \mathrm{min}^{-1 / 2}\right)\end{array}$} \\
\hline Sorbent & $\begin{array}{c}\mathrm{q}_{\exp } \\
\left(\mathrm{mg} \cdot \mathrm{g}^{-1}\right)\end{array}$ & $\begin{array}{c}\mathrm{K}_{1} \\
\left(\min ^{-1}\right)\end{array}$ & $\begin{array}{c}\mathrm{q}_{1} \\
\left(\mathrm{mg} \cdot \mathrm{g}^{-1}\right)\end{array}$ & $\mathrm{r}_{2}$ & $\frac{\mathrm{K}_{2}}{\left(\mathrm{~g} \cdot \mathrm{mg}^{-1} \cdot \mathrm{min}^{-1}\right.}$ & $\begin{array}{c}\mathrm{q}_{2} \\
\left(\mathrm{mg} \cdot \mathrm{g}^{-1}\right)\end{array}$ & $\mathrm{r}^{2}$ & \\
\hline $\begin{array}{c}\text { Air-dried, AD } \\
\left(\mathrm{C}_{0}=10 \mathrm{mg} \cdot \mathrm{g}^{-1}\right)\end{array}$ & 4.50 & $5.95 \times 10^{-2}$ & 3.96 & 0.455 & $1.69 \times 10^{-2}$ & 4.39 & 0.619 & 0.14 \\
\hline $\begin{array}{l}\text { Freeze-dried, FD } \\
\left(\mathrm{C}_{0}=10 \mathrm{mg} \cdot \mathrm{g}^{-1}\right)\end{array}$ & 5.89 & $2.78 \times 10^{-2}$ & 5.93 & 0.908 & $6.16 \times 10^{-3}$ & 6.34 & 0.887 & 1.24 \\
\hline $\begin{array}{c}\text { Chitosan } \\
\left(\mathrm{C}_{0}=10 \mathrm{mg} \cdot \mathrm{g}^{-1}\right)\end{array}$ & 3.74 & 0.177 & 3.44 & 0.757 & 0.11 & 3.56 & 0.851 & $2.81 \times 10^{-2}$ \\
\hline $\begin{array}{c}\mathrm{FD} \\
\left(\mathrm{C}_{0}=20 \mathrm{mg} \cdot \mathrm{g}^{-1}\right)\end{array}$ & 7.39 & 0.129 & 6.88 & 0.778 & $3.9 \times 10^{-2}$ & 7.13 & 0.885 & 0.64 \\
\hline
\end{tabular}

Furthermore, increasing the initial concentration of neodymium (Figure 6b), increased the uptake in the initial and the second sections of the kinetic profiles: the contact time for achieving the equilibrium is reduced ( $4.5 \mathrm{~h}$ are required for reaching complete saturation plateau). It means that an increase of the metal concentration involves an increase of the concentration gradient between the solution and the internal/external surface of the ChiFer(III) material; as a consequence, the driving force increases which also involves a faster migration of ions and a higher sorption rate [45].

Moreover, Rorrer et al. [55] pointed out that a pore blockage mechanism may occur at low metal concentrations; the sorbed species flux is low, resulting in the accumulation of the sorbate species at the entrance to the porous network, which could finally block the external cavity of the pore. This mechanism was not completely evidenced in this study.

\subsection{Dynamic System}

In sorption processes, an important task for determining the feasibility of a promising sorbent is the capability of being used in a continuous system. Columns experiments are very useful to approach the real applications in the treatment of industrial effluents; although most of the results, currently present in the literature are reported on the batch system; the relevance of columns must be highlighted since the assessment of the monitoring parameters (such as flow rate, inlet metal concentration, $\mathrm{pH}$, internal diameter of the column, and bed-depth of the packed sorbent) leads to improve the design and enhances the scaling-up of the sorption technique as a function of the sewage characteristics.

The simplicity of using a fixed amount of packed sorbent for treating large volumes of polluted waters (instead of a batch configuration) involves a better engineering conception of the material; the operating time could be easier optimized and the unnecessary treatment steps could be avoided (such as filtration of the loaded sorbent). According to the experimental data, the breakthrough curves were plotted for neodymium removal from dilute aqueous solutions, the sorption capacities were calculated until the breaking $\left(\mathrm{q}_{\mathrm{BP}}\right)$ and exhaustion $\left(\mathrm{q}_{\mathrm{exp}}\right)$ points.

Figure 7 shows the typical S-shape of the curves, by using two different flow rates $(0.01$ and $0.02 \mathrm{~L} \cdot \mathrm{h}^{-1}$ ); two common steps can be noted: (i) a first step where the neodymium species are totally sorbed; and (ii) a second step characterized by the progressive appearance of the metal, due to the continuous competition for occupying the active sites into the sorbent [56]. 

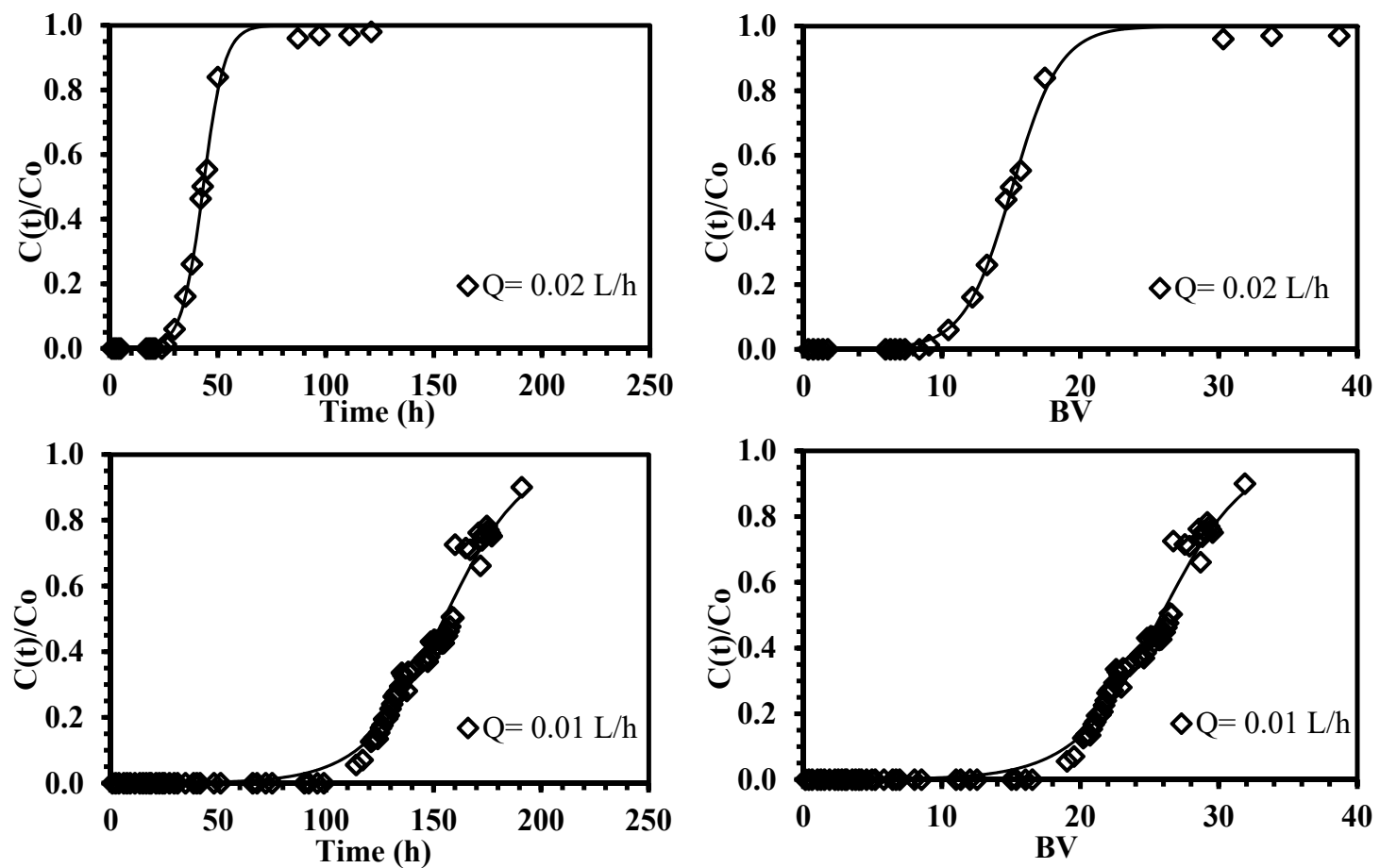

Figure 7. Continuous sorption of neodymium using ChiFer(III) material as fixed-packed sorbent. (Left side: Breakthrough curves as a function of time; right side: Breakthrough curves as a function of bed-volume; solid line: Thomas model; T: $20^{\circ} \mathrm{C}$; internal diameter of the column, $\varnothing: 1.8 \mathrm{~cm}$; bed depth: $23 \mathrm{~cm}$; flow rate: $0.01-0.02 \mathrm{~L} \cdot \mathrm{h}^{-1}$; $\left.\mathrm{pH}: 4 ; \mathrm{C}_{0}: 10.2 \mathrm{mg} \cdot \mathrm{Nd}(\mathrm{III}) \cdot \mathrm{L}^{-1}\right)$.

The breakthrough curves are similar in shape, but in terms of breakthrough time are substantially different; a decrease in the superficial velocity involves an increase of the effectiveness of the process; approximately $5 \%$ of the feed concentration is leached from the column after nine bed-volumes using a flow rate of $0.02 \mathrm{~L} \cdot \mathrm{h}^{-1}$; this result is improved when the flow rate is halved (i.e., $0.01 \mathrm{~L} \cdot \mathrm{h}^{-1}$ ), the sorption efficiency is increased from $25 \%$ to $79 \%$ and 19 bed-volumes are required for achieving the breaking point (Table 4). These differences are directly related to the residence time for mass transfer; when the higher superficial velocity is used, the external film diffusion is reduced, thus faster breaking and saturation times are produced. These findings are in agreement with the results obtained by Muhamad et al. [57] and Demey et al. [45] on heavy metal removal on using the biosorption process.

Table 4. Sorption parameters for continuous system using ChiFer(III) material as sorbent.

\begin{tabular}{|c|c|c|c|c|c|c|c|c|}
\hline \multicolumn{6}{|c|}{ Experimental } & \multicolumn{3}{|c|}{ Thomas Parameters } \\
\hline Sorbate & $\begin{array}{c}\mathrm{Q} \\
\left(\mathrm{L} \cdot \mathrm{h}^{-1}\right)\end{array}$ & $\begin{array}{c}\mathrm{qexp} \\
\left(\mathrm{mg} \cdot \mathrm{g}^{-1}\right)\end{array}$ & $\begin{array}{c}\text { Sorption } \\
\text { Efficiency } \\
(\%)\end{array}$ & $\begin{array}{c}\mathrm{qBP}_{\mathrm{BP}} \\
\left(\mathrm{mg} \cdot \mathrm{g}^{-1}\right)\end{array}$ & $\begin{array}{l}\text { Bed-Volume } \\
\left(\mathrm{BV}_{\mathrm{BP}}\right)\end{array}$ & $\frac{\mathrm{q}_{\mathrm{T}}}{\left(\mathrm{mg} \cdot \mathrm{g}^{-1}\right)}$ & $\begin{array}{c}\mathrm{K}_{\mathrm{T}} \\
\left(\mathrm{L} \cdot \mathrm{h}^{-1} \cdot \mathrm{mg}^{-1}\right)\end{array}$ & $r^{2}$ \\
\hline $\mathrm{Nd}$ & 0.02 & 4.02 & 24.97 & 2.12 & 9.06 & 3.46 & $1.98 \times 10^{-2}$ & 0.984 \\
\hline $\mathrm{Nd}$ & 0.01 & 6.40 & 79.17 & 4.79 & 19.03 & 6.55 & $5.27 \times 10^{-3}$ & 0.981 \\
\hline
\end{tabular}

Additionally, the sorption capacity obtained in the exhaustion point $\left(\mathrm{q}_{\exp }\right)$ is two times lower of that obtained in the batch system (i.e., $13.76 \mathrm{mg} \cdot \mathrm{g}^{-1}$ in batch system and $6.40 \mathrm{mg} \cdot \mathrm{g}^{-1}$ in column system); this fact was attributed by Kleinübing et al. [58] to the resistance to the film diffusion which was particularly active in dilute concentrations (below $0.5 \mathrm{mmol} \cdot \mathrm{L}^{-1}$ ), on the continuous removal of copper and nickel from aqueous solutions with marine alga species; the mass transfer could be improved by reducing the flow rate. 
ChiFer(III) material was evaluated in this work through three consecutive sorption/desorption cycles (in the batch system using $0.1 \mathrm{mmol} \cdot \mathrm{L}^{-1}$ neodymium solutions, Figure $\mathrm{S} 6$ ); the performance of the beads drastically decreased from the third sorption cycle (i.e., it drops from $99.1 \%$ in the first cycle to $30.3 \%$ in the third cycle). It is noteworthy that ChiFer(III) was previously tested for boron recovery from seawater in several sorption-desorption cycles; the stability of the material and its performance was not affected under extreme saline conditions [23]. Thus, further studies will be performed in order to enhance the reusability of the sorbent with real effluents (containing boron and neodymium), which will be the scope of a future work. In order to verify the selectivity sequence of the sorbed metals, an equimolar solution of boron and neodymium $\left(0.1 \mathrm{mmol} \cdot \mathrm{L}^{-1}\right)$ was passed into the column; this influent was prepared to approach a real application of metal recovery from dilute waste waters of permanent magnets (Nd-Fe-B).

The breakthrough curves from the binary mixture are plotted in Figure 8; three relevant features are highlighted: (i) the first step of the sorption curve is more prolonged for neodymium than for boron, which is evidence of the higher selectivity toward Nd ions; (ii) a significant reduction of the bed-volumes on neodymium appearance was obtained (in comparison with single metal solution, the bed-volume values were reduced from 19 to 3.9); the process becomes less efficient, this is a consequence of the strong competition of species for active sites into the sorbent material; iii) boron in presence of neodymium is eluted from the column in a shorter time ( $5 \%$ of the feed boron concentration is leached after 0.5 bed-volumes), thus, boron overshoot is produced: the outlet concentration is higher than inlet concentration (i.e., $C / C_{o}>1$ ). The overshoot in a column system is based on the proper nature of the sorption itself, the sorbent has a limited sorption capacity and the species with lower affinity are pushed off and displaced by the species of higher affinity [59]; this phenomenon is in agreement with Sag and Kutsal, [60].
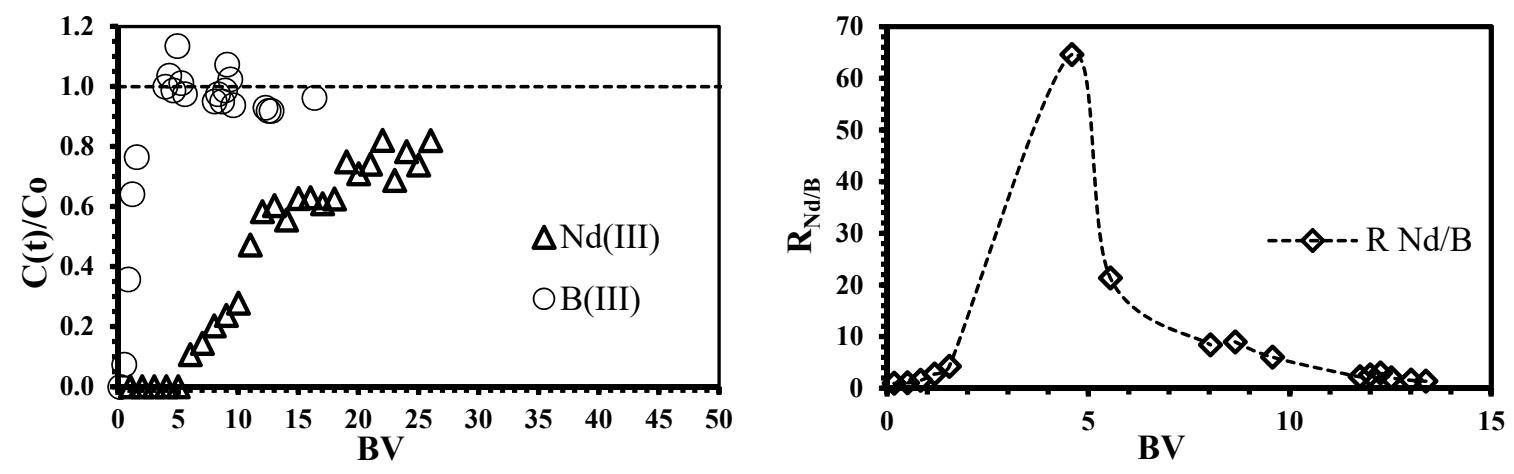

Figure 8. Simultaneous sorption of neodymium and boron using ChiFer(III) material as fixed-packed sorbent. (Left side: Breakthrough curves as a function of Bed-volume (BV), dashed line: overshooting guide line; right side: Separation coefficient $\mathrm{R}_{\mathrm{Nd} / \mathrm{B}}$ as a function of $\mathrm{BV}$; dashed line: experimental trend; T: $20^{\circ} \mathrm{C}$; internal diameter of the column, $\varnothing: 1.8 \mathrm{~cm}$; bed depth: $23 \mathrm{~cm}$; flow rate: $0.01 \mathrm{~L} \cdot \mathrm{h}^{-1}$; pH: $\left.4 ; \mathrm{C}_{0}: 0.1 \mathrm{mmol} \cdot \mathrm{L}^{-1}\right)$.

Although the sorption of boron species (as co-ions) is almost negligible, due to the higher selectivity to $\mathrm{Nd}$ ions, the removal uptake of neodymium is inhibited (the sorption performance decreases from $79 \%$ in single solution to $49 \%$ in binary system, Tables 4 and S1). Some authors have suggested that the non-binding co-ions contribute to balancing the negative charges on the biomass surface (i.e., the electro-neutrality principle); this could inhibit electrostatically the binding of the main metal even though the co-ion is not bound to the sorbent [61]. The sorption mechanism onto iron surface was reported by Smith and Ghiassi, [62] and Grossl et al. [63] by using iron particles and goethite, respectively, as sorbents for chromate removal; the modeling results suggested the formation of monodentate inner-sphere complexes onto iron particles and bidentate inner-sphere complexes onto goethite. However, the interaction between the iron(III) hydroxide and boron species occurs 
similarly to an esterification reaction: both boric acid and borate ions can react with the hydroxide compounds to form the boric and borate esters [64]; this mechanism can only take place if the distance between adjacent $\mathrm{OH}^{-}$groups in the $\mathrm{Fe}(\mathrm{OH})_{3}$ structure are similar to those of $\mathrm{OH}^{-}$groups of boron species $[23,64]$.

The separation factor for equimolar solutions $\left(\mathrm{R}_{\mathrm{Nd} / \mathrm{B}}\right)$ was plotted as a function of bed-volume (Figure 8). The values of $R_{N d / B}>>1$ confirm the higher neodymium selectivity of the sorbent; as expected, the point of maximum separation degree corresponds to 4.6 bed-volumes, which is also the point of the maximum overshooting of boron; consequently, the affinity of ChiFer(III) follows $\mathrm{Nd}>>\mathrm{B}$. The regeneration of the column was carried out with dilute $\mathrm{HCl}$ solution (demineralized water at $\mathrm{pH} 3.5$ ); Figure 9 shows that only $0.6 \mathrm{~L}$ of eluent is enough for metal recovery: $20 \%$ of the total sorbed $\mathrm{Nd}$ and $30 \%$ of boron (it represents the remaining boron which was not previously overshot). The possibility of recovering the sorbed metals from the loaded ChiFer(III), makes this sorbent interesting for future separation of neodymium from real effluents.
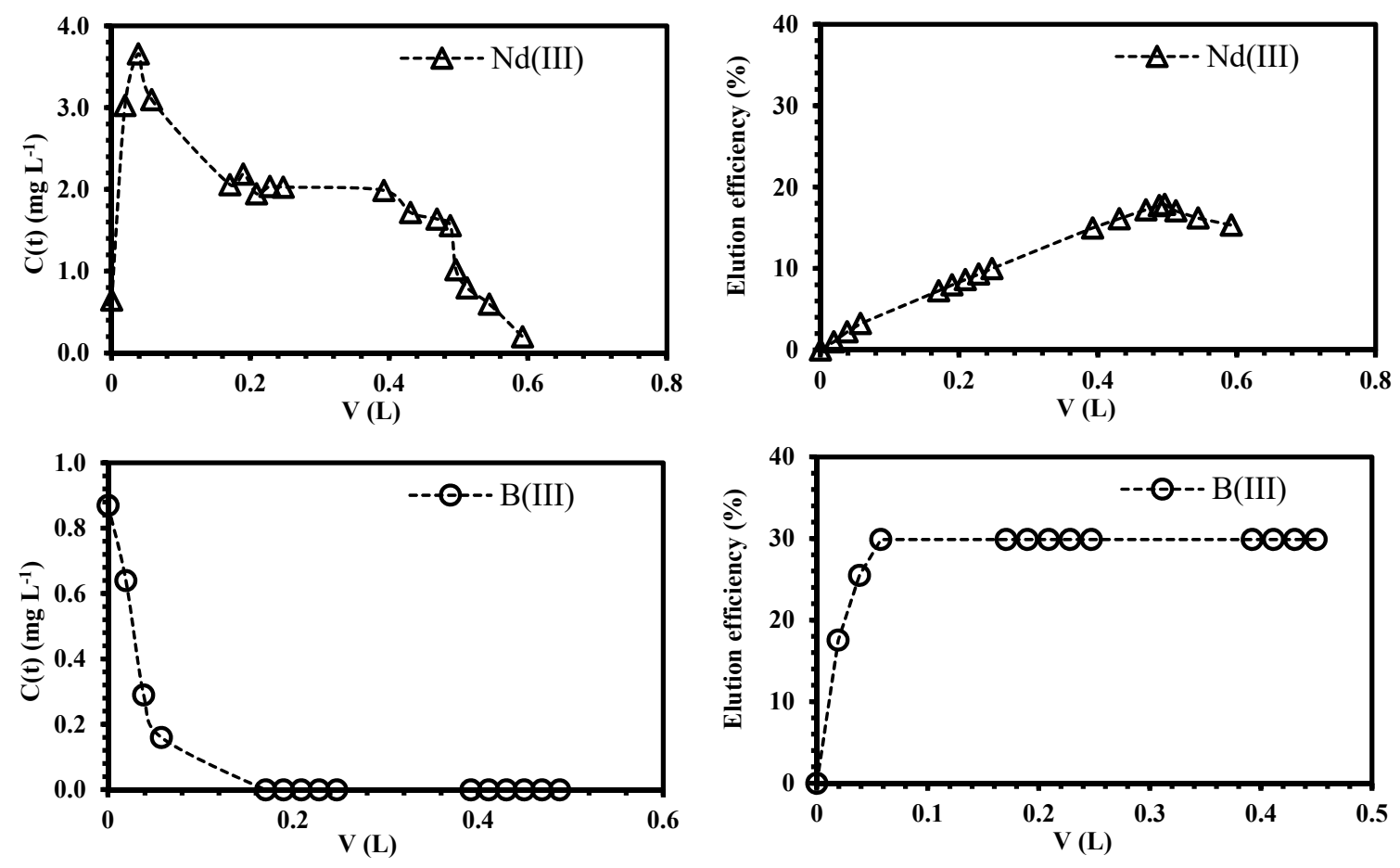

Figure 9. Simultaneous desorption of neodymium and boron from loaded ChiFer(III) material as fixed-packed sorbent. (Left side: Recovery metal concentration as a function of the volume (L), dashed line: desorption trend; right side: Elution efficiency as a function of the volume (L); dashed line: efficiency trend; T: $20^{\circ} \mathrm{C}$; internal diameter of the column, $\varnothing: 1.8 \mathrm{~cm}$; bed depth: $23 \mathrm{~cm}$; flow rate: $0.01 \mathrm{~L} \cdot \mathrm{h}^{-1}$; Eluent: demineralized water at $\left.\mathrm{pH}: 3.5\right)$.

\section{Conclusions}

ChiFer(III) material is a promising and efficient sorbent for neodymium recovery from effluent waters. The incorporation of iron(III) hydroxide into the chitosan matrix, improves the sorption efficiency of the resulting material. The maximum sorption capacities obtained were $3.5 \mathrm{mg} \cdot \mathrm{g}^{-1}$ and $13.8 \mathrm{mg} \cdot \mathrm{g}^{-1}$ by using chitosan and ChiFer(III), respectively. The Sips model and PSORE fitted accurately the sorption isotherms and the kinetic experimental data, respectively. Column experiments demonstrated the feasibility of recycling the sorbents; the regeneration of the packed-bed can be performed with only $0.6 \mathrm{~L}$ of eluent (demineralized water at $\mathrm{pH}$ 3.5). The evaluations with simulated effluent of boron and neodymium demonstrated the higher selectivity of the sorbent toward Nd ions, which is useful for future evaluations with real wastewater effluents; the faster overshooting of boron 
in the columns enhances the separation of neodymium. The continuous sorption data can be described by the Thomas equation.

Supplementary Materials: The supplementary materials are available online at http:/ /www.mdpi.com/20734360/10/2/204/s1.

Acknowledgments: This work was supported by the Spanish Ministry of Economy and Competitiveness, MINECO (Projects CTM20014-52770-R and CTM2017-83581-R). The authors would like to thank M. Dominguez and T. Trifonov (from Universitat Politecnica de Catalunya) for their technical assistance in this work. Byron Lapo would like to thank to C. Quezada, A. Borja, and J. Perez from Universidad Técnica de Machala for their special interest in this research topic.

Author Contributions: Hary Demey, Byron Lapo, Montserrat Ruiz, Agustin Fortuny, Muriel Marchand and Ana M. Sastre conceived and designed the experiments; Hary Demey and Byron Lapo performed the tests and collected the experimental data; the manuscript was written by Hary Demey and Byron Lapo. The revision of the results interpretations were performed by Ana M. Sastre, Montserrat Ruiz, Agustin Fortuny, and Muriel Marchand.

Conflicts of Interest: The authors declare no conflict of interest.

\section{References}

1. Cossu, R.; Williams, I.D. Urban mining: Concepts, terminology, challenges. Waste Manag. 2015, 45, 1-3. [CrossRef] [PubMed]

2. Oddo, G. Die molekularstruktur der radioaktiven atom. Z. Aanorg. Allg. Chem. 1914, 87, 253-268. [CrossRef]

3. Harkins, W.D. The evolution of the elements and the stability of complex atoms. I. A new periodic system which shows a relation between the abundance of the elements and the structure of the nuclei of atoms. J. Am. Chem. Soc. 1917, 39, 856-879. [CrossRef]

4. Tu, Y.J.; Lo, S.C.; You, C.F. Selective and fast recovery of neodymium from seawater by magnetic iron oxide $\mathrm{Fe}_{3} \mathrm{O}_{4}$. Chem. Eng. J. 2015, 262, 966-972. [CrossRef]

5. Rademaker, J.H.; Kleijn, R.; Yang, Y.X. Recycling as a strategy against rare earth element criticality: A systemic evaluation of the potential yield of NdFeB magnet recycling. Environ. Sci. Technol. 2013, 47, 10129-10136. [CrossRef] [PubMed]

6. U.S. Department of Energy. Critical Materials Strategy, Advanced Research Projects Agency-Energy; U.S. Department of Energy: Washington, DC, USA, 2011.

7. Mirbagheri, S.A.; Hosseini, S.N. Pilot plan investigation on petrochemical wastewater treatment for the removal of copper and chromium with the objective of reuse. Desalination 2005, 171, 85-93. [CrossRef]

8. Özverdi, A.; Erdem, M. $\mathrm{Cu}^{2+}, \mathrm{Cd}^{2+}$ and $\mathrm{Pb}^{2+}$ adsorption from aqueous solutions by pyrite and synthetic iron sulphide. J. Hazard. Mater. 2006, 137, 626-632. [CrossRef] [PubMed]

9. Aji, B.A.; Yavuz, Y.; Koparal, A.S. Electrocoagulation of heavy metals containing model wastewater using monopolar iron electrodes. Sep. Purif. Technol. 2012, 86, 248-254. [CrossRef]

10. Chen, G. Electrochemical technologies in wastewater treatment. Sep. Purif. Technol. 2004, 38, 11-41. [CrossRef]

11. Blöcher, C.; Dorda, J.; Mavrov, V.; Chmiel, H.; Lazaridis, N.K.; Matis, K.A. Hybrid flotation-membrane filtration process for the removal of heavy metal ions from wastewater. Water Res. 2003, 37, 4018-4046. [CrossRef]

12. Samper, E.; Rodriguez, M.; De la Rubia, M.A.; Prats, D. Removal of metal ions at low concentration by micellar-enhanced ultrafiltration (MEUF) using sodium dodecyl sulfate (SDS) and linear alkylbenzene sulfonate (LAS). Sep. Purif. Technol. 2009, 65, 337-342. [CrossRef]

13. Obon, E.; Fortuny, A.; Coll, M.T.; Sastre, A.M. Mathematical modeling of neodymium, terbium and dysprosium solvent extraction from chloride media using methyl-tri(octyl/decyl)ammonium oleate ionic liquid as extractant. Hydrometallurgy 2017, 173, 84-90. [CrossRef]

14. Edebali, S.; Pehlivan, E. Evaluation of chelate and cation exchange resins to remove copper ions. Powder Technol. 2016, 301, 520-525. [CrossRef]

15. Kang, S.Y.; Lee, J.U.; Moon, S.H.; Kim, K.W. Competitive adsorption characteristics of $\mathrm{Co}^{2+}, \mathrm{Ni}^{2+}$, and $\mathrm{Cr}^{3+}$ by IRN-77 cation exchange resin in synthesized wastewater. Chemosphere 2004, 56, 141-147. [CrossRef] [PubMed] 
16. Elwakeel, K.Z.; Guibal, E. Selective removal of $\mathrm{Hg}$ (II) from aqueous solution by functionalized magnetic-macromolecular hybrid material. Chem. Eng. J. 2015, 281, 345-359. [CrossRef]

17. Mahfouz, M.G.; Galhoum, A.A.; Gomaa, N.A.; Abdel-Rehem, S.S.; Atia, A.A.; Vincent, T.; Guibal, E. Uranium extraction using magnetic nano-based particles of diethylenetriamine-functionalized chitosan: Equilibrium and kinetic studies. Chem. Eng. J. 2015, 262, 198-209. [CrossRef]

18. Demey, H.; Tria, S.A.; Soleri, R.; Guiseppi-Elie, A.; Bazin, I. Sorption of his-tagged Protein G and Protein G onto chitosan/divalent metal ion sorbent used for detection of microcystin-LR. Environ. Sci. Pollut. Res. Int. 2017, 24, 15-24. [CrossRef] [PubMed]

19. Zhuo, N.; Lan, Y.; Yang, W.; Yang, Z.; Li, X.; Zhou, X.; Liu, Y.; Shen, J.; Zhang, X. Adsorption of three selected pharmaceuticals and personal care products (PPCPs) onto MIL-101(Cr)/natural polymer composite beads. Sep. Purif. Technol. 2017, 177, 272-280. [CrossRef]

20. Pavon, S.; Kutucu, M.; Coll, M.T.; Fortuny, A.; Sastre, A.M. Comparison of Cyanex 272 and Cyanex 572 on the separation of Neodymium from a Nd/Tb/Dy mixture by pertraction. J. Chem. Technol. Biotechnol. 2017. [CrossRef]

21. Yurekli, Y. Removal of heavy metals in wastewater by using zeolite nano-particles impregnated polysulfone membranes. J. Hazard. Mater. 2016, 309, 53-64. [CrossRef] [PubMed]

22. Oladipo, A.A.; Gazi, M. Targeted boron removal from highly-saline and boron-spiked seawater using magnetic nanobeads: Chemometric optimisation and modelling studies. Chem. Eng. Res. Des. 2017, 121, 329-338. [CrossRef]

23. Demey, H.; Vincent, T.; Ruiz, M.; Nogueras, M.; Sastre, A.M.; Guibal, E. Boron recovery from seawater with a new low-cost adsorbent material. Chem. Eng. J. 2014, 254, 463-471. [CrossRef]

24. Wang, F.; Zhao, J.; Wei, X.; Huo, F.; Li, W.; Huo, Q.; Liu, H. Adsorption of rare earths (III) by calcium alginate-poly glutamic acid hybrid gels. J. Chem. Technol. Biotechnol. 2014, 89, 969-977. [CrossRef]

25. Galhoum, A.A.; Mafhouz, M.G.; Abdel-Rehem, S.T.; Gomaa, N.A.; Atia, A.A.; Vincent, T.; Guibal, E. Cysteine-functionalized chitosan magnetic nano-based particles for the recovery of light and heavy rare earth metals: Uptake kinetics and sorption isotherms. Nanomaterials (Basel) 2015, 5, 154-179. [CrossRef] [PubMed]

26. Zhao, F.; Repo, E.; Meng, Y.; Wang, X.; Yin, D.; Sillanpää, M. An EDTA- $\beta$-cyclodextrin material for the adsorption of rare earth elements and its applications in preconcentration of rare earth elements in seawater. J. Colloid Interface Sci. 2016, 465, 215-224. [CrossRef] [PubMed]

27. Zhao, F.; Repo, E.; Song, Y.; Yin, D.; Hammouda, S.B.; Chen, L.; Kalliola, S.; Tang, J.; Tam, K.C.; Sillanpää, M. Polyethylenimine-cross-linked cellulose nanocrystals for highly efficient recovery of rare earth elements from water and mechanism study. Green Chem. 2017, 19, 4816-4828. [CrossRef]

28. Wang, G.H.; Liu, J.S.; Wang, X.G.; Xie, Z.Y.; Deng, N.S. Adsorption of uranium (VI) from aqueous solutions onto cross-linked chitosan. J. Hazard. Mater. 2009, 168, 1053-1058. [CrossRef] [PubMed]

29. Hosoba, M.; Oshita, K.; Katarina, R.K.; Takayanagi, T.; Oshima, M.; Motomizu, S. Synthesis of novel chitosan resin possessing histidine moiety and its application to the determination of trace silver by ICP-AES coupled with triplet automated-pretreatment system. Anal. Chim. Acta 2009, 639, 51-56. [CrossRef] [PubMed]

30. Thomas, H.C. Heterogeneous ion exchange in a flowing system. J. Am. Chem. Soc. 1944, 66, 1664-1666. [CrossRef]

31. Ruiz, M.; Sastre, A.M.; Zikan, M.C.; Guibal, E. Palladium sorption on glutaraldehyde-crosslinked chitosan in fixed-bed systems. J. Appl. Polym. Sci. 2001, 81, 153-165. [CrossRef]

32. Guibal, E.; Larkin, A.; Vincent, T.; Tobin, J.M. Chitosan sorbents for platinum sorption from dilute solutions. Ind. Eng. Chem. Res. 1999, 38, 401-412. [CrossRef]

33. Langmuir, I. The adsorption of gases on plane surfaces of glass, mica and platinum. J. Am. Chem. Soc. 1918, 40, 1361-1403. [CrossRef]

34. Freundlich, H.M.F. Über die adsorption in lösungen. Z. Phys. Chem. 1906, 57A, 385-470. [CrossRef]

35. El-Korashy, S.A.; Elwakeel, K.Z.; El-Hafeiz, A.A. Fabrication of bentonite/thiourea-formaldehyde composite material for $\mathrm{Pb}(\mathrm{II}), \mathrm{Mn}(\mathrm{VII})$ and $\mathrm{Cr}(\mathrm{VI})$ sorption: A combined basic study and industrial application. J. Clean. Prod. 2016, 137, 40-50. [CrossRef]

36. Zhao, F.; Repo, E.; Yin, D.; Chen, L.; Kalliola, S.; Tang, J.; Iakovleva, E.; Tam, K.C.; Sillanpää, M. One-pot synthesis of trifunctional chitosan-EDTA- $\beta$-cyclodextrin polymer for simultaneous removal of metals and organic micropollutants. Sci. Rep. 2017, 7, 1-14. [CrossRef] [PubMed] 
37. Weber, W.J.; Morris, J.C. Kinetics of adsorption on carbon from solutions. J. Sanit. Eng. Div. ASCE 1963, $89,31-60$.

38. Lagergreen, S. Zur theorie der sogenannten adsorption gelöster stoffe. Kungliga Svenska Vetenskapsakademiens. Handlingar 1898, 24, 1-39.

39. Shi, X.; Li, Q.; Wang, T.; Lackner, K.S. Kinetic analysis of an anion exchange absorbent for $\mathrm{CO}_{2}$ capture from ambient air. PLoS ONE 2017, 12, 1-12. [CrossRef] [PubMed]

40. Ho, Y.S.; McKay, G. Sorption of dye from aqueous solution by peat. Chem. Eng. J. 1998, 70, 115-124. [CrossRef]

41. Chu, K.H. Fixed bed sorption: Setting the record straight on the Bohart-Adams and Thomas models. J. Hazard. Mater. 2010, 177, 1006-1012. [CrossRef] [PubMed]

42. Wang, F.; Zhao, J.; Zhou, H.; Li, W.; Sui, N.; Lui, H. O-carboxymethyl chitosan entrapped by silica: Preparation and adsorption behavior toward neodymium (III) ions. J. Chem. Technol. Biotechnol. 2013, 88, 317-325. [CrossRef]

43. Ruiz, M.; Sastre, A.M.; Guibal, E. Pd and Pt recovery using chitosan gel beads: I. Influence of drying process on diffusion properties. Sep. Sci. Technol. 2002, 37, 2143-2166. [CrossRef]

44. Borisova, A.; De Bruyn, M.; Budarin, V.L.; Shuttleworth, P.S.; Dodson, J.R.; Segatto, M.L.; Clark, J.H. A sustainable freeze-drying route to porous polysaccharide with tailored hierarchical meso-and macroporosity. Macromol. Rapid Commun. 2015, 36, 774-779. [CrossRef] [PubMed]

45. Demey, H.; Vincent, T.; Guibal, E. A novel algal-based sorbent for heavy metal removal. Chem. Eng. J. 2018, 332, 582-595. [CrossRef]

46. Gazi, M.; Shahmohammadi, S. Removal of trace boron from aqueous solutions using iminobis-(propylene glycol) modified chitosan beads. React. Funct. Polym. 2012, 72, 680-686. [CrossRef]

47. Demey, H.; Vincent, T.; Ruiz, M.; Sastre, A.M.; Guibal, E. Development of a new chitosan/Ni(OH $)_{2}$-based sorbent for boron removal. Chem. Eng. J. 2014, 244, 576-586. [CrossRef]

48. Shinde, T.J.; Gadkari, A.B.; Vasambekar, P.N. Influence of $\mathrm{Nd}^{+3}$ substitution on structural, electrical and magnetic properties of nanocrystalline nickel ferrites. J. Alloy Compd. 2012, 513, 80-95. [CrossRef]

49. Sakai, Y.; Hayano, K.; Yoshioka, H.; Yoshioka, H. A novel method of dissolving chitosan in water for industrial applications. Polym. J. 2001, 33, 640-642. [CrossRef]

50. Sorlier, P.; Viton, C.; Domard, A. Relation between solution properties and degree of acetylation of chitosan: Role of aging. Biomacromolecules 2002, 3, 1336-1342. [CrossRef] [PubMed]

51. El-Sonbati, A.Z.; El-Deen, I.M.; El-Bindary, M.A. Adsorption of hazardous azorhodanine dye from an aqueous solution using rice straw fly ash. J. Dispers. Sci. Technol. 2016, 37, 715-722. [CrossRef]

52. Vlachou, A.; Symeopoulos, B.D.; Koutinas, A.A. A comparative study of neodymium sorption by yeast cells. Radiochim. Acta 2009, 97, 437-441. [CrossRef]

53. Guo, J.; Cai, J.; Su, Q. Ion imprinted polymer particles of neodymium: Synthesis, characterization and selective recognition. J. Rare Earth 2009, 27, 22-27. [CrossRef]

54. Benettayeb, A.; Guibal, E.; Morsli, A.; Kessas, R. Chemical modification of alginate for enhanced sorption of $\mathrm{Cd}(\mathrm{II}), \mathrm{Cu}(\mathrm{II})$ and $\mathrm{Pb}(\mathrm{II})$. Chem. Eng. J. 2017, 316, 704-714. [CrossRef]

55. Rorrer, G.L.; Hsien, T.Y.; Way, J.D. Synthesis of porous-magnetic chitosan beads for removal of cadmium ions from waste water. Ind. Eng. Chem. Res. 1993, 32, 2170-2178. [CrossRef]

56. Chu, K.H. Improved fixed bed models for metal biosorption. Chem. Eng. J. 2004, 97, 233-239. [CrossRef]

57. Muhamad, H.; Doan, H.; Lohi, A. Batch and continuous fixed-bed column biosorption of $\mathrm{Cd}^{2+}$ and $\mathrm{Cu}^{2+}$. Chem. Eng. J. 2010, 158, 369-377. [CrossRef]

58. Kleinübing, S.J.; Da Silva, E.A.; Da Silva, M.G.C.; Guibal, E. Equilibrium of Cu(II) and Ni(II) biosorption by marine alga Sargassum filipendula in a dynamic system: Competitiveness and selectivity. Bioresour. Technol. 2011, 7, 4610-4617. [CrossRef] [PubMed]

59. Escudero, C.; Poch, J.; Villaescusa, I. Modelling of breakthrough curves of single and binary mixtures of $\mathrm{Cu}(\mathrm{II}), \mathrm{Cd}(\mathrm{II}), \mathrm{Ni}(\mathrm{II})$ and $\mathrm{Pb}(\mathrm{II})$ sorption onto grape stalks waste. Chem. Eng. J. 2013, 217, 129-138. [CrossRef]

60. Sag, Y.; Kutsal, T. Recent trends in the biosorption of heavy metals: A review. Biotechnol. Bioprocess Eng. 2001, 6, 376-385. [CrossRef]

61. Shiewer, S.; Volesky, B. Ionic strength and electrostatic effects in biosorption of divalent metal ions and protons. Environ. Sci. Technol. 1997, 31, 2478-2485. [CrossRef] 
62. Smith, E.; Ghiassi, K. Chromate removal by an iron sorbent: Mechanism and modeling. Water Environ. Res. 2006, 78, 84-93. [CrossRef] [PubMed]

63. Grossl, P.R.; Eick, M.J.; Sparks, D.L.; Goldberg, S.; Ainsworth, C.C. Arsenate and chromate retention mechanisms on goethite. 2. Kinetic evaluation using a pressure-jump relaxation technique. Environ. Sci. Technol. 1997, 31, 321-326. [CrossRef]

64. Ruiz, M.; Tobalina, C.; Demey-Cedeño, H.; Barron-Zambrano, J.A.; Sastre, A.M. Sorption of boron on calcium alginate gel beads. React. Funct. Polym. 2013, 73, 653-657. [CrossRef] 